\title{
Vanuatu: 2011 Article IV Consultation-Staff Report; Debt Sustainability Analysis; and Public Information Notice on the Executive Board Discussion
}

Under Article IV of the IMF's Articles of Agreement, the IMF holds bilateral discussions with members, usually every year. In the context of the 2011 Article IV consultation with Vanuatu, the following documents have been released and are included in this package:

- $\quad$ The staff report for the 2011 Article IV consultation, prepared by a staff team of the IMF, following discussions that ended on March 10, 2011, with the officials of Vanuatu on economic developments and policies. Based on information available at the time of these discussions, the staff report was completed on April 8, 2011. The views expressed in the staff report are those of the staff team and do not necessarily reflect the views of the Executive Board of the IMF.

- $\quad$ A Debt Sustainability Analysis of April 11, 2011.

- $\quad$ A Public Information Notice (PIN) summarizing the views of the Executive Board as expressed during its April 22, 2011 discussion of the staff report that concluded the Article IV consultation.

The policy of publication of staff reports and other documents allows for the deletion of market-sensitive information.

\author{
Copies of this report are available to the public from \\ International Monetary Fund • Publication Services \\ $70019^{\text {th }}$ Street, N.W. • Washington, D.C. 20431 \\ Telephone: (202) 623-7430 • Telefax: (202) 623-7201 \\ E-mail: publications@imf.org Internet: http://www.imf.org
}

\section{International Monetary Fund Washington, D.C.}




\section{INTERNATIONAL MONETARY FUND}

\section{VANUATU}

\section{STAFF REPORT FOR THE 2011 ARTICLE IV CONSULTATION}

April 8, 2011

\section{KEY ISSUES}

A gradual rebound. GDP growth is expected to pick up to 33/4 percent this year on the back of stronger investment growth, expanding tourism arrivals, and higher copra production. Key downside risks are delays in infrastructure investment and a longer-thanprojected impact of natural disasters in Australia and New Zealand on tourism. The surge in global commodity prices is projected to push inflation up to 4 percent in 2011.

Managing the rebound. The key near-term challenge is to support economic recovery, while moving toward fiscal consolidation and guarding against high inflation.

- In 2011, it will be important to stick to the overall budget expenditure ceiling to underscore the government's commitment to fiscal consolidation. If output growth falls below projections, revenue should be allowed to function as an automatic stabilizer. A broadly balanced budget in 2012 will restore the much needed fiscal space to respond to future shocks.

- It is time to begin tightening monetary conditions. Inflation pressures have emerged, and banks have ample liquidity for lending.

- $\quad$ Pressures on foreign exchange reserves are building and if they persist the vatuwhich is moderately overvalued according to staff analysis—should be allowed to depreciate.

Enhancing resilience to shocks. Maintaining large fiscal, external, and financial buffers will help Vanuatu's economy be more resilient to shocks. On the fiscal side, this will require the government to mobilize revenue, facilitate smoother donor financing, reduce the wage bill, and improve state-owned enterprise efficiency and transparency. On the external side, the government should be vigilant in keeping its foreign reserves at an adequate level. In the financial sector, banking supervision should be intrusive and the regulatory framework and supervisory skills should be strengthened. 
Approved By

Subir Lall and Thomas Dorsey
Discussions took place in Port Vila during March 2-10, 2011. The staff team comprised Mr. Feyzioglu (head; OMD), Mr. Ide, and Ms. Lin (both APD).

\section{CONTENTS}

INTRODUCTION

A GRADUAL REBOUND

A. Recent Economic Developments

B. Outlook and Risks

MANAGING THE REBOUND

ENHANCING RESILENCE TO SHOCKS

A. Safeguarding Fiscal Soundness

B. Ensuring an Adequate Level of Foreign Reserves

C. Strengthening Financial Stability

STAFF APPRAISAL

\section{BOXES}

1. Exchange Rate Assessment

2. Key Elements of Revenue Mobalization

3. Reserve Adequacy

\section{FIGURES}

1. Economic Developments

2. Macroeconomic Policy Developments

\section{TABLES}

1. Selected Economic and Financial Indicators, 2006-11___ 22

2. Balance of Payments, 2006-11___ 23

3. Central Government Fiscal Operations, 2006-11___ 24

4. Monetary Survey, 2004-10___ 25

5. Medium-Term Baseline Scenario, 2006-16___ 26

6. Social Indicators __ 27

7. Vulnerability Indicators, 2006-11__ 28

8. Millennium Development Goals ___ 29 


\section{INTRODUCTION}

1. As a small open economy, Vanuatu is facing the dual challenge of large fluctuations on the external side and a limited production base on the domestic side. Its natural beauty and unique amalgamation of different cultures provide good opportunities for tourism. At the same time, its small population and distance to major markets form large barriers to manufacturing. Agricultural production is so far limited to a few products. As a result, recent sharp increases in global commodity prices and the temporary but significant drop in tourist arrivals have adversely affected both the

\section{A GRADUAL REBOUND}

\section{A. Recent Economic Developments}

3. Economic activity is showing signs of a moderate rebound (Table 1, Figure 1). All three engines of growth had stalled in 2009 and early 2010: copra production had fallen in response to a sharp decline in global copra prices, the launch of a number of infrastructure projects had been delayed, and tourism had declined after temporarily surging to exceptionally high levels at the onset of the global financial crisis as Australian tourists switched to closer holiday destinations like Vanuatu. Later in 2010, positive signs in external demand began to emerge. Tourism - particularly cruise ship arrivalsstarted to pick up, and global copra prices surged, incentivizing more copra production. Domestic external accounts and the domestic markets. Looking forward, external shocks will continue to have a significant impact on Vanuatu's economy.

2. Vanuatu is well placed to manage these macroeconomic challenges. It benefits from good macroeconomic fundamentals and a supportive international community. Continuing to invest in its people and strengthen its institutions and macroeconomic tools and buffers would go a long way in attaining strong sustainable growth.

demand indicators also began to strengthen, supported by accommodative macro policies: loans to households increased, private investment in tourism and commercial real estate picked uppartially financed with cash-imports for domestic use continued to rise, and energy consumption rebounded.

4. Inflation bottomed out in the third quarter of 2010 and is ticking up due to both demand and supply pressures. CPI inflation jumped to 3.4 percent year/year $(y / y)$ in the fourth quarter of 2010 from 2.3 percent the previous quarter, reversing the downward trend during the last two years. While the main culprit was food 


\section{Figure 1 Vanuatu-Economic Developments}

The Vanuatu economy weathered the financial crisis relatively well...

Real GDP Growth

(Year-on-year percent change)

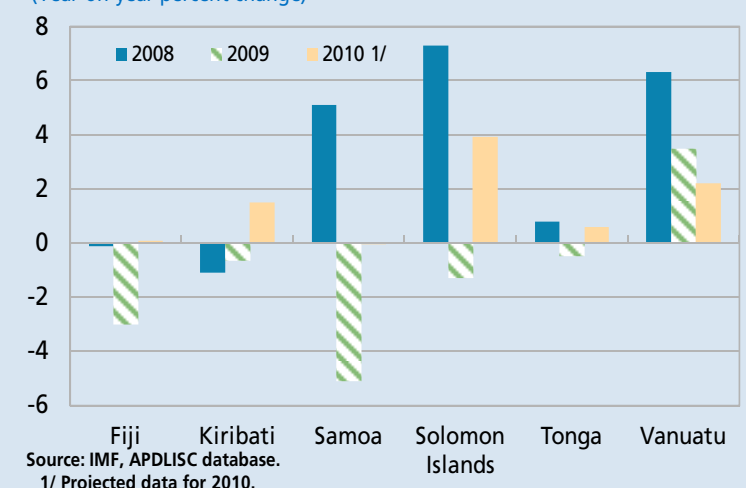

1/ Projected data for 2010.

...partly owing to lower tourist arrivals as Australians returned to long-haul destinations.

Visitor Arrivals: Contribution to Growth by Country of Origin (Year-on-year percent change)

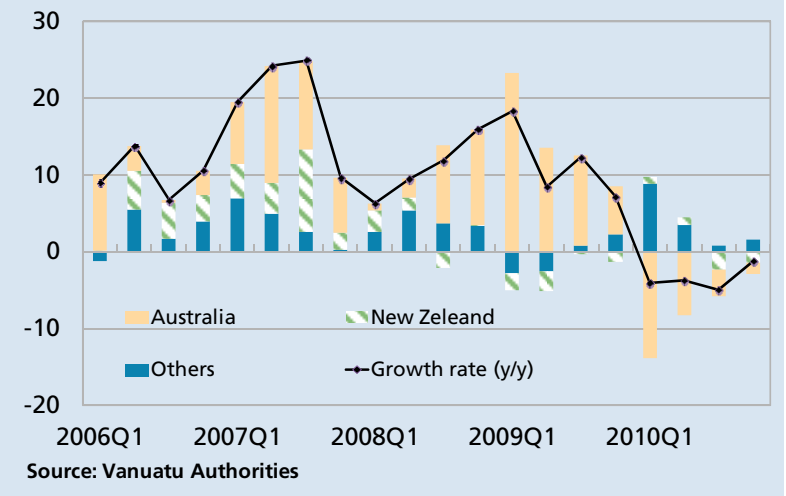

The current account has remained in deficit, with continued large trade imbalances.

Balance of Payments

(In percent of GDP)

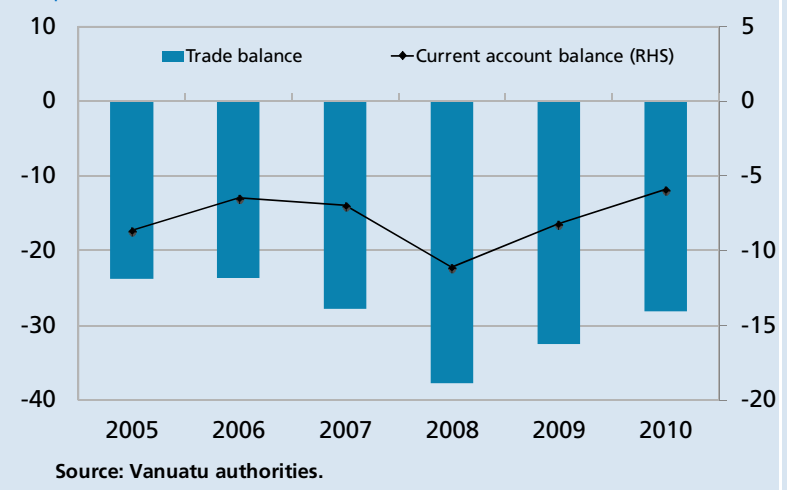

but both industrial and services sectors slowed down...

Contribution to GDP Growth by Sector

(Year-on-year percent change)

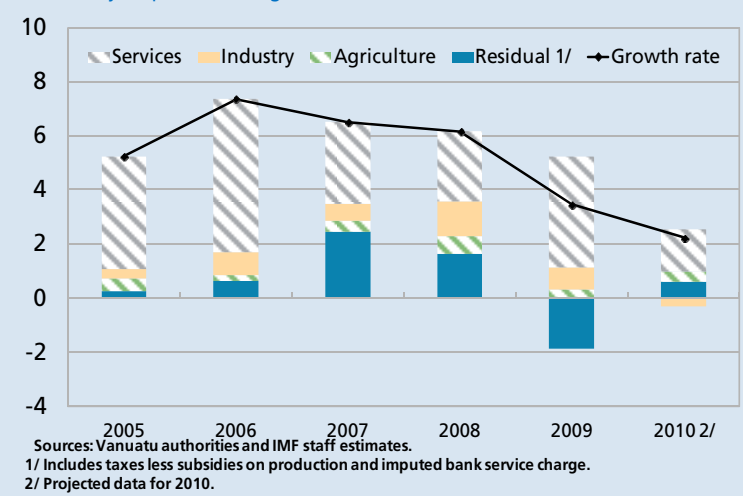

Food price increases began to push inflation up in recent months.

Contribution to Inflation

(Year-on-year percent change)

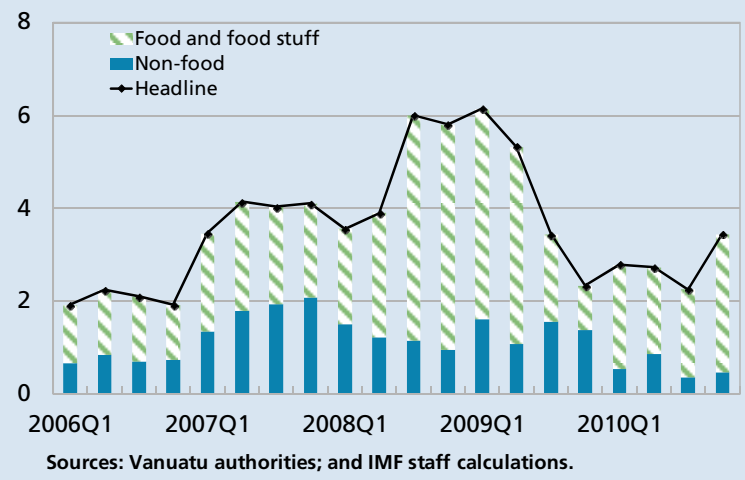

Reserves remained stable in 2010, after increasing substantially in 2009, partly reflecting the SDR allocation.

Foreign Reserves

(In millions of U.S. dollars)

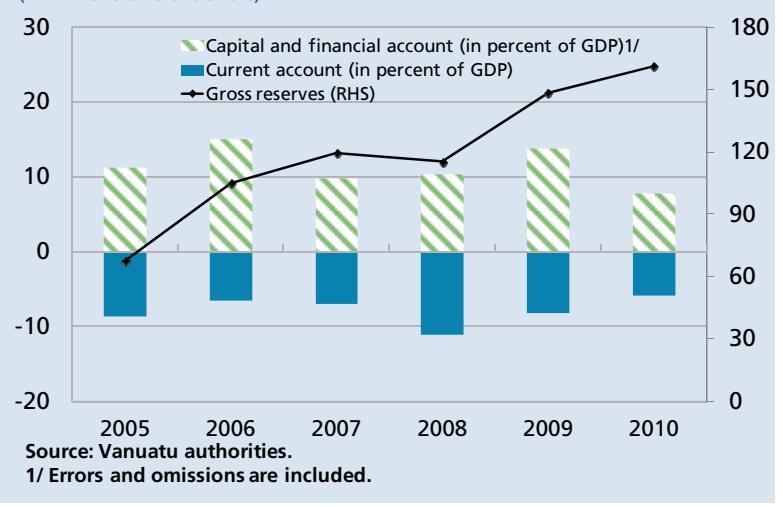


prices, most other components of the consumption basket also increased. The rise in inflation was partially capped by the reduction in fees for healthcare services and introduction of free primary education in 2010.

5. The balance of payments has been stable (Table 2). The goods and services trade

\section{B. Outlook and Risks}

\section{Staff's Views}

6. Economic activity should continue to rebound in the near term. Copra production should remain strong, as global copra prices are expected to remain elevated. Private investment is projected to continue to grow, supported by loans to households and government's efforts to boost Vanuatu's tourism sector. A number of infrastructure projects should also commence later in 2011, further encouraging growth in the manufacturing and construction sectors. The spike in cruise ship arrivals also bodes well for tourism, despite a decline in air travel in early 2011, which is low season for Vanuatu. Combined, GDP growth is projected to rise moderately to 33/4 percent in 2011 and strengthen further in 2012, given the momentum and plans to initiate additional infrastructure projects next year.

\section{Inflation is projected to reach 4 percent} in 2011 on the back of higher food and oil prices as well as strengthening domestic demand. The risks are on the upside, primarily from rising global commodity prices. deficit remained high at 7 percent of GDP in 200910 , but was fully financed by strong FDI inflows and official grants, including disbursements from the Millennium Challenge Account (MCA). The level of reserves was stable around $\$ 150-\$ 160$ million (covering six months of imports) in 2010 after rising throughout 2009 (helped by the SDR allocation of $\$ 26$ million).

\section{There are downside risks to this growth} outlook. First, infrastructure projects that are supposed to commence this year may be further delayed. Second, the impact of recent natural disasters-the devastating floods in Australia, the earthquake in New Zealand, and the cyclone that hit several Vanuatu islands - could be more lasting on tourism and trade than currently projected.

\section{The Authorities' Views}

\section{The authorities broadly agreed with} staff's assessment of the growth outlook. They concurred that the economy was gradually bouncing back from last year's lows. They conservatively projected GDP to grow by 3 percent this year, based on more pessimistic expectations of growth in tourism and inclusion of the potential impact of additional cyclones that might hit the region during the rest of the rainy season. Risks were mostly on the upside and the authorities highlighted a number of measures they were implementing to further boost the chances of stronger growth. These included a marketing campaign initiated to promote Vanuatu's tourism with a view to gain market share in the 
region, and measures to cut red tape to facilitate quicker investment decisions and to encourage agricultural production in a variety of products. They thought growth would strengthen further to 4 percent in 2012 as the full impact of the new infrastructure projects take hold in the economy.

10. The authorities also agreed with the inflation outlook. They project inflation to rise throughout 2011 and average 3.9 percent for the year. While they expect competition in communication services and renewal of utility contracts in more favorable terms to ease some price pressures, they consider overall risks to be on the upside, stemming from commodity prices and the recent cyclone that damaged crops in Vanuatu.

\section{MANAGING THE REBOUND}

The economic slowdown during 2009-10 had worsened the fiscal position and now the global commodity price surge is exacerbating inflationary pressures. The key near-term policy challenge is to support economic recovery, while moving toward fiscal consolidation and guarding against high inflation.

\section{Background}

11. In 2010, the fiscal deficit deteriorated to an estimated 2.7 percent of GDP as revenue fell well short of budget projections (Table 3, Figure 2). Total revenue excluding grants shrunk 2.4 percent from 2009, compared with a budgeted increase of 17 percent, reflecting weaknesses in revenue from both external trade and domestic activity. Recognizing early on the likely shortfall in revenue, the authorities implemented expenditure cuts across the board and restrained total expenditure to 7.3 percent below the budget.

12. For 2011, the authorities are targeting a substantial reduction in the deficit to
0.7 percent of GDP. They expect to achieve this reduction mainly by capping the wage bill broadly at the 2010 level and lowering capital expenditure, albeit to still historically high levels. The budget still provides for a number of social projects that are government priority, in particular the universal primary education initiative, with support from foreign partners.

\section{The Reserve Bank of Vanuatu (RBV) has been maintaining its easy monetary stance established at the onset of the global financial crisis (Table 4). In late 2008, the RBV had lowered the rediscount rate by 25 bps to 6 percent and had reduced the Statutory Reserve Deposit (SRD) requirement by 300 bps to 5 percent.}




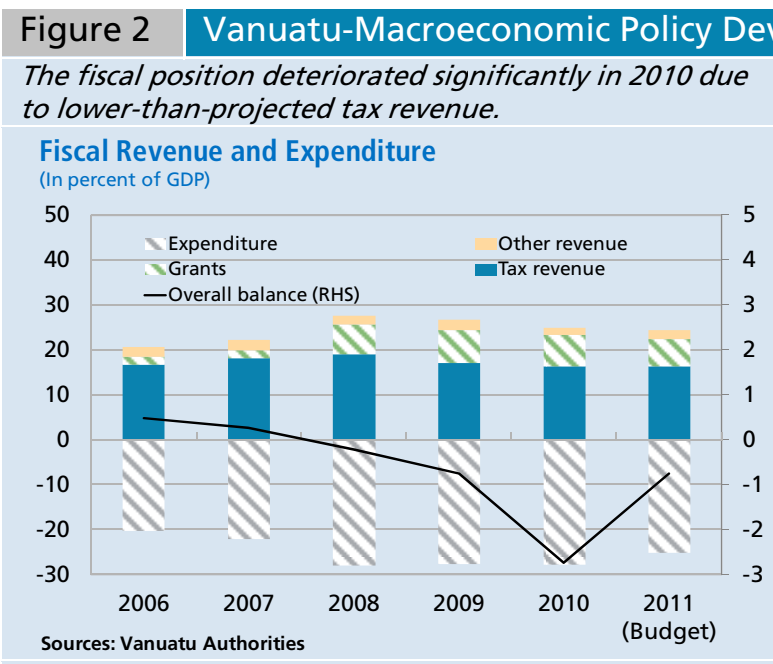

The RBV kept the rediscount rate broadly unchanged for the last five years...

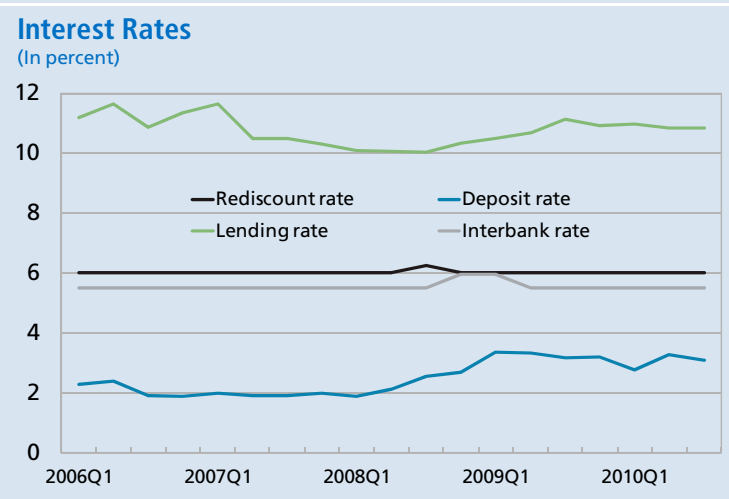

Source: Vanuatu authorities

Credit growth declined to still strong levels after surging in response to the entry of a new foreign bank.

Money Supply and Credit Growth

(3mma, year-on-year percent change)

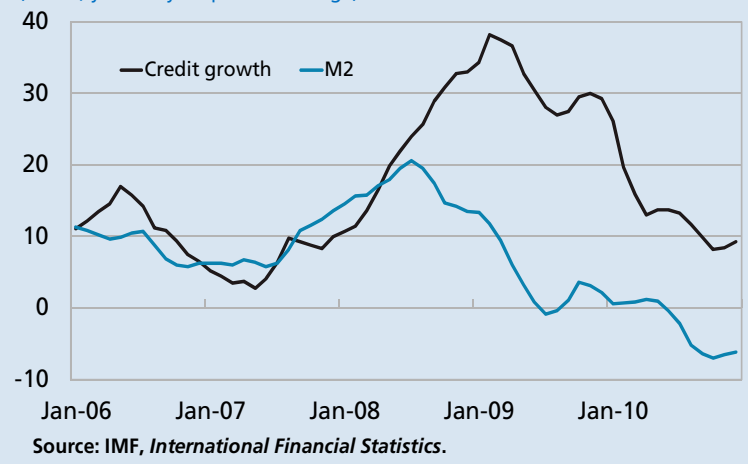

The government debt remains at low levels thanks to the authorities' fiscal consolidation efforts in the $2000 \mathrm{~s}$

Public Debt

(In percent of GDP)

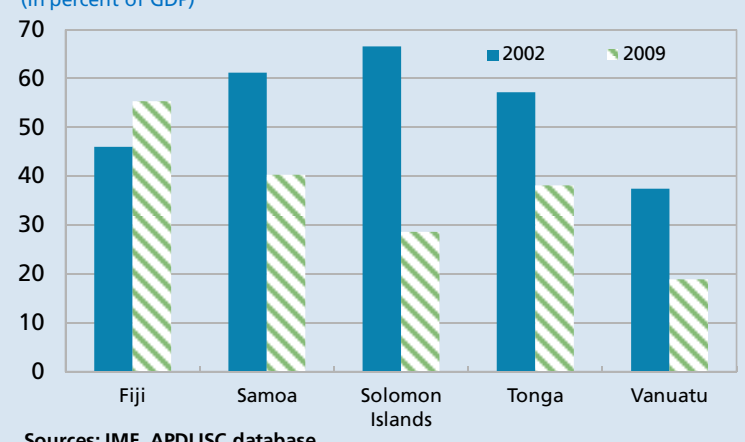

Sources: IMF, APDLISC database

... and in the third quarter of 2010 raised the statutory deposit requirement, but injected liquidity through open market operations

Commercial Bank's Liquidity

(In millions of Vatu)

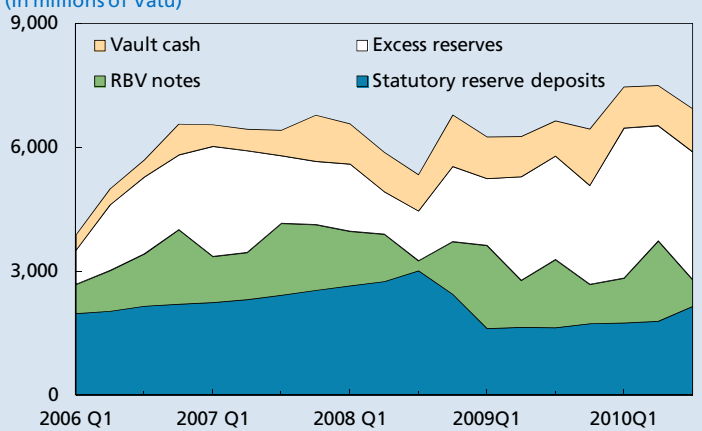

Source: Vanuatu authorities.

The Vatu remained broadly stable in 2010.

Effective Exchange Rates

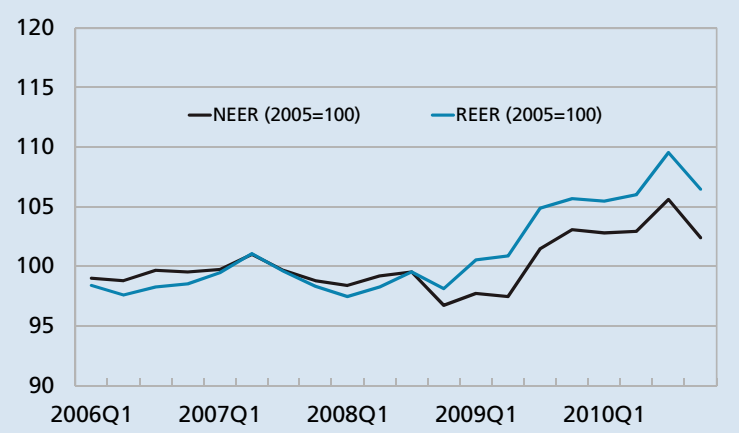

Sources: Vanuatu authorities; and IMF, Informaton Notice System. 
In August 2010, the RBV increased the SRD requirement by 100 bps to 6 percent, withdrawing liquidity amounting to 0.5 billion vatu. However, during the same quarter, the RBV reduced its open market operations and injected in net terms 1 billion vatu compared to the same period the previous year. These operations also compensated for the declining government deposits (used to finance the deficit) and helped banks continue to expand credit to the private sector at a relatively strong pace of 12 percent (y/y) in the last quarter of 2010 (Table 4). Lending to households picked up significantly and foreign currency-denominated loans surged. Banks financed these loans partly by borrowing from abroad, increasing their foreign liabilities. At the same time banks' foreign assets shrunk, partly mimicking the reduction in foreign-denominated deposits. As a result, net foreign assets of the banks were halved in 2010.

\section{The vatu has moved little in effective terms since 2009 and is assessed to be moderately overvalued relative to its medium-}

term fundamentals (Box 1). The standard modelbased assessment methods suggest an overvaluation of around 8-13 percent, with large margins of error. Other indicators are mixed but on balance also point to an overvaluation. In particular, net foreign assets of the banking system have been declining since early 2010, and the goods trade deficit remains much larger than the surplus in the services sector.

\section{Staff's Views}

15. The fiscal stance in 2010 was appropriate and set the right stage for this year. Faced with a slowing economy and sharply lower-than-projected revenue, the authorities found the right balance between allowing some fiscal loosening and restraining overall expenditure growth.

16. For 2011, it will be important to stick to the overall budget expenditure ceiling. Achieving the expenditure targets will reaffirm the government's commitment to fiscal consolidation, and maintain confidence in public finances. Particular attention should be given to ensuring that the wage bill is contained. On the revenue side, there are downside risks mainly as growth may turn out to be lower than currently projected. Total revenue should be allowed to function as an automatic stabilizer should it fall short of projections because of weaker output growth. The shortfall should be made up next year to broadly balance the budget, thus creating room for fiscal policy to respond to future shocks. Maintaining fiscal deficits at around the 2010 level in 2011 and beyond would lead public debt to eventually exceed prudent levels (Appendix 1).

\section{It is time to begin tightening monetary} conditions. The RBV responded appropriately to the global financial crisis by easing monetary conditions in a timely manner. Against the backdrop of a global recovery led by emerging and developing economies, inflation pressures have emerged, including in Vanuatu. This year's inflation is expected to be at the top end of the RBV's target range of $0-4$ percent. Moreover, ample liquidity in the banking system is leading to sharp increases in lending to households. To contain inflation pressures and restrain credit growth, it is appropriate to tighten monetary 


\section{Box 1 Exchange Rate Assessment}

Vanuatu's exchange rate is assessed to be moderately overvalued relative to its medium-term fundamentals based on standard analytical approaches. Other indicators are more mixed. There is considerable uncertainty in these results mainly because external balances are heavily influenced by a small number of factors (tourism and foreign aid) and these factors could be quite volatile going forward.

\section{Standard Exchange Rate Assessment Methods}

The macroeconomic balance approach suggests that a depreciation of about 13 percent in real effective terms could bring the current account deficit to its equilibrium level of around $2 \frac{1}{2}$ percent of GDP, which is determined as a function of fundamentals relative to Vanuatu's trading partners. These fundamentals include the fiscal balance, economic growth, income, foreign aid, and demographics.

The equilibrium real exchange rate approach suggests that vatu is above its equilibrium level by around 8 percent in real effective terms. The equilibrium value of the real effective exchange rate is estimated as a function of factors that affect long run purchasing power parity, ${ }^{2}$ including the terms of trade, net foreign assets, and foreign aid.

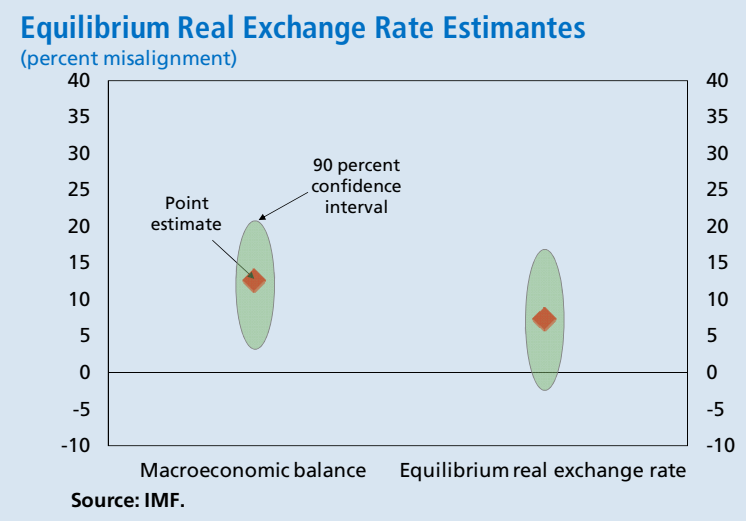

\section{Other indicators}

- Foreign reserves are currently at an adequate level, but are projected to decline as a share of GDP over the medium term as the economy grows. Moreover, net foreign assets of the banking system declined by 35 percent (20 percent of broad money) in 2010, primarily reflecting the decline in foreign assets and the increase in foreign liabilities held by banks, suggesting that pressures on foreign assets are building up in the financial system. Reflecting these pressures, the vatu depreciated close to 2 percent in effective terms in the first two months of 2011 and official reserves declined by 1.2 percent in December 2010.

- While the goods trade deficit is large (29 percent of GDP), surpluses in the service sector, and grants compensate for this deficit. However, to reduce this dependency on grants in the medium run, the goods trade deficit should be reduced and the services surplus increased.

- Tourism receipts are projected to pick up. In the short run, there are downside risks from floods in Australia and the earthquake in New Zealand, but in the longer run this sector is expected to be an engine of growth in Vanuatu.

- Inflation has been moderate. There are no signs of sustained downward pressures on goods prices that would bring about a depreciation of the vatu in effective terms.

\footnotetext{
${ }_{1}^{1}$ Prepared by Huidan Lin.

${ }^{2}$ Due to lack of data, government consumption as a share of GDP and PPP GDP per employment are not included in the regression.
} 
conditions. Since the impact of changes in the policy rate on bank lending rates has traditionally been weak, consideration should be given to further raising SRD requirements. In addition, efforts should be stepped up to ensure that banks lending to households is based on sound credit risk assessments and, if necessary, prudential policies should be tightened.

\section{The pickup in foreign currency-} denominated lending and the reduction in the net foreign assets of the banks are of concern. Currently these loans are extended only to those entities that generate foreign currency revenues; however, such lending cannot be naturally hedged indefinitely and will lead to a buildup of systemic risk in currency mismatch. Foreign currency lending should be monitored carefully and if the current trends continue, prudential measures on foreign currency lending should be put in place.

\section{The exchange rate should be allowed to support macroeconomic adjustment.}

Pressures on foreign exchange reserves are on the downside with the recent surge in global commodity prices, which are expected to be long lasting and create a persistent negative terms of trade shock on Vanuatu. In fact, the decline in net foreign assets of the banks suggests that there is already an imbalance between demand and supply of foreign currency. Should this imbalance persist and continue to exert pressure on foreign reserves, the vatu should be allowed to depreciate in effective terms - within the current exchange rate framework-with appropriate adjustments to monetary policy to take into account additional increases in import prices. Resisting persistent depreciation pressures would exacerbate the pressures and increase the cost of adjustment.

\section{The Authorities' Views}

20. The authorities agreed on the importance of moving toward fiscal consolidation. They were confident that they would be able to hold total expenditure at or below the budgeted levels this year. They pointed out that the single treasury account provides them with an effective tool to limit payments to items that are already budgeted, including salaries and wages for each line ministry. At this stage, they did not have any plans to pass a supplementary budget and stressed that any additional expenditure would be allowed only if it is associated with additional revenue. On the revenue side, they were taking a number of administrative measures to boost tax collection (see below) and had the view that these measures would raise sufficient revenue to reach the budget target this year. For next year, they were aiming for a broadly balanced budget, but it was too early to commit to any particular figure at this stage of the budget process. The authorities anticipated official grants-including direct budget support-to be larger next year and help achieve a balanced budget.

\section{The authorities plan to gradually tighten monetary conditions going forward.} They were concerned about upside risks to the inflation outlook and the rapid increase in bank lending to households and lending in foreign currency. They acknowledged that indirect instruments were less effective when used alone 
and noted that they would also make use of direct instruments. They are closely monitoring the liquidity situation in the banking system and taking into account the government's plans to borrow from the domestic market so as to avoid a temporary liquidity squeeze. They are also considering prudential measures (see below) to cool foreign currency lending.
22. The authorities appreciated the work done by staff on the equilibrium level of the vatu. They noted that broad political buy-in was needed to bring more flexibility to the exchange rate.

\section{ENHANCING RESILENCE TO SHOCKS}

Vanuatu's economy lacks sufficient opportunities for diversification and has few natural shock absorbers. Maintaining large fiscal, external, and financial buffers would make the economy more resilient to adverse shocks and support sustainable growth over the medium term.

\section{A. Safeguarding Fiscal Soundness}

\section{Background}

23. Vanuatu's fiscal position is sound. Public debt is low at 20 percent of GDP and the government deficits have been small for a number of years. Last year the government reconfirmed its commitment to fiscal sustainability by capping expenditure to below the budgeted levels to reduce the deficit and by adopting a budget that targeted a much smaller deficit this year.

24. To safeguard this strong fiscal position, a number of structural issues need to be addressed:

- Low revenue. Total revenue at 18 percent of GDP (excluding grants) is low compared with other Pacific Island Countries (PICs).
Moreover, the share of revenue in total output is expected to decline further over the medium term, owing to regional initiatives to lower tariffs. Such low and possibly declining revenue may not be able to support large expenditure needs in the future. It also narrows the space for automatic stabilizers to work, further limiting the ability of the government to respond to shocks.

- High wage bill. The public sector wage bill accounts for more than 40 percent of total public expenditure, and the ratio remains one of the highest among PICs. Coupled with low revenue, the high wage bill further suppresses the ability of the government to 
support expanding social spending and infrastructure investment needs.

- Inefficient SOEs and other quasigovernment entities. Most of these entities drain budgetary resources and produce very low returns (in 2010, transfers to these entities were 8 percent of current expenditure). Importantly, contingent liabilities may have been accumulating in some of these entities, but publicly available information is scarce.

\section{Staff's Views}

25. The government should consider a number of options to strengthen revenue. In deciding which options to utilize, consideration should be given to their efficiency, equity, feasibility, and contribution to macroeconomic stability (Box 2):

- Introducing income tax. This tax has two important advantages: it has the potential to raise significant revenue over the medium run and also make the tax system more equitable. Losing the competitive advantage of being a tax haven could be partially offset by further improving the business climate, including by reducing red tape.

- Raising the current tax rates. There may be scope to raise the VAT rate from 12.5 percent to 15 percent, which would be on par with the highest rate in the region. However, such a rate hike would have an adverse impact on the poor since this is a regressive tax. Excise taxes could also be raised further.

- Improving tax administration and compliance. Eliminating tax leakages by strengthening collection from large taxpayers and businesses, improving customs controls, and ensuring correct declaration of land purchase prices could help raise revenue.

\section{The authorities and donors should} facilitate smoother donor financing. Foreign donors provide substantial funds to support Vanuatu's development. However, utilization of these funds is lumpy, causing large fluctuations in overall economic activity. Foreign and Vanuatu authorities should work together to improve the predictability of donor financing and government implementation of projects supported by foreign donors.

\section{The wage bill should be reduced.} Spending should be reoriented away from government employment toward areas that support inclusive long-term growth. In particular, the wage bill allocated to the education sector could be reduced by improving efficiency in this sector and linking salaries to qualifications. Reallocation of spending should help encourage private sector growth and create new opportunities for current government employees. It will also reduce structural rigidities on the expenditure side. The illustrative alternative scenario depicted in the table below suggests that boosting non-grant 
Vanuatu's tax revenue to GDP ratio, at 18 percent, is one of the lowest within the PICs and on par with the average for low-income countries. VAT, excises, and import duties account for about 80 percent of tax revenue in Vanuatu and there is no corporate or personal income tax. The main characteristics of the current tax system and revenue performance are as follows:

- VAT. The VAT rate is 12.5 percent. The current rate is broadly in line with peers in the region, where the maximum VAT rate is 15 percent. Exemptions are relatively limited.

- Excises. Excises are levied on alcohol, tobacco, fuels, seafood, meat, flour and sugar related products. The rates have been increased from low levels in recent years to partially compensate for the decline in import duties.

- Import duties. Import duties are levied on a large range of goods. They account for about 6 percent of GDP, which is broadly in line with peers in the region. Although import duties are currently one of the major components of tax revenue, they are expected to decline gradually due to trade liberalization in the region.

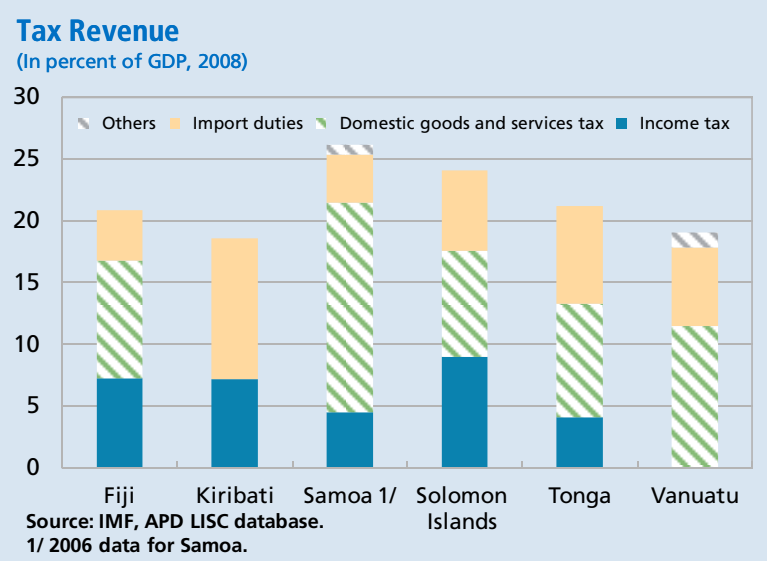

2006 data for Samoa.

Revenue mobilization measures should take into account efficiency, equity, feasibility, and ability to contribute to macroeconomic stability.
In particular, the following elements could be considered when taking measures such as introducing an income tax, raising current tax rates, and improving tax administration: ${ }^{2}$

- Efficiency. An efficient tax system leaves economic choices the same as they would have been without taxes. A VAT is generally considered more efficient, as a single rate VAT with a broad base could raise revenue without distorting economic decisions. Minimizing exemptions would also help promote efficiency. An income tax, on the other hand, is considered less efficient, as it could distort economic choices.

- Equity. An equitable tax system can be achieved by promoting both horizontal equity (taxpayers with similar incomes pay similar amount of taxes) and vertical equity (those with higher incomes pay higher amount of taxes). A progressive income tax is generally considered suitable to promote vertical equity. Some progressivity can also be achieved under a VAT by allowing exemptions for necessity goods and/or setting higher rates for luxury goods, but these approaches may undermine efficiency.

- Feasibility. A well-designed tax system should be aligned with the tax administration capacity to collect revenue. Given the authorities' capacity constraints, enforcement resources should be focused on large taxpayers rather than small taxpayers whose monitoring generally requires significant resources.

- Macroeconomic stability. A tax system that has a broader and more stable base could allow fiscal automatic stabilizers to work more predictably and effectively.

\footnotetext{
${ }^{1}$ Prepared by Joji Ide.

${ }^{2}$ IMF (2010), Tax Policy and Administration (TPA-TTF), Draft Program Document IMF (2010).
} 
revenue to 20 percent of GDP could provide room to finance infrastructure projects without jeopardizing social spending or debt sustainability. enterprises caused a net drain on VAT revenues. The authorities did not think that introduction of an income tax would raise much revenue and did not

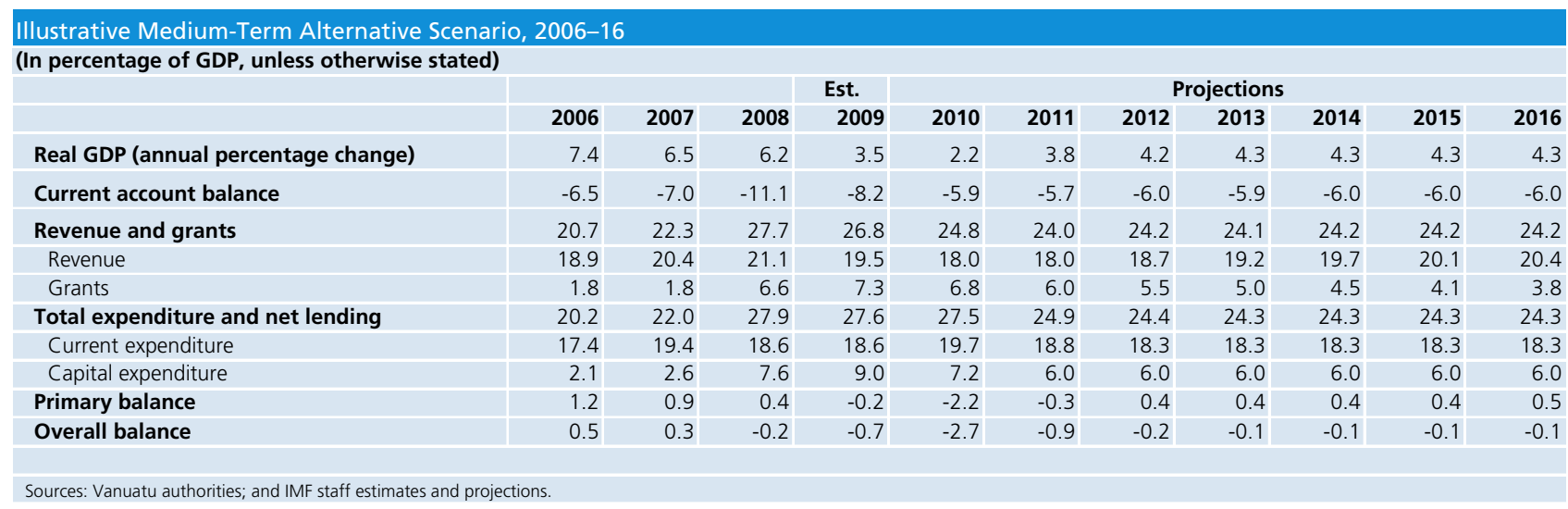

\section{SOE efficiency and transparency}

should be improved. The monitoring framework for the SOEs should be strengthened and SOEs that make continuous losses should be restructured, sold, or closed. A comprehensive review of the sector, possibly with external support, could help facilitate these changes. The SOE reform would reduce the need for budgetary support, increase dividends, and lead to improvements in the business climate, which would help raise Vanuatu's overall growth potential.

\section{The Authorities' Views}

\section{The authorities recognized the need to} mobilize additional revenue. They considered this could be done by intensifying inspections at customs, increasing penalties for avoiding VAT payments, and enforcing truthful declarations of value in land transactions, which are subject to stamp duties. They were also considering tightening the conditions for voluntary inclusion of small- and medium-size enterprises in the VAT system, as these consider it to be equitable because rich residents would find ways to avoid paying high income tax and companies would pass the tax burden on fully to consumers owing to lack of competition in the domestic economy. Nevertheless, they agreed that introduction of an income tax could remain an option to be considered in the medium term. They noted that they had time because regional trade agreements would not significantly lower customs revenues in the short run since rates in Vanuatu are already below the thresholds that are being negotiated.

\section{The authorities were keen to improve} the predictability of funds received from external donors. Two units were recently established in the Prime Minister's office to coordinate and evaluate foreign aid flows. Both project financing and direct budget financing were welcome; however, the authorities acknowledged that capacity constraints in line ministries were hampering efforts to implement some projects. They also noted that some donor funds earmarked 
for Vanuatu lacked flexibility and payment schedules did not necessarily match the project schedules.

\section{The authorities were considering their} options to improve public services while reducing the wage bill. Since half of the government employees are in the education sector, the government is considering the feasibility of improving the quality of education while reducing the number of employees in this sector. They noted that already per capita spending on education was high, and that quality improvements could be achieved without straining the budget. In the healthcare sector, outsourcing management of hospitals and clinics is being considered. The government is also planning to initiate a review of government service provision next year. This year, a number of directors general were put under contract with a view to increase their accountability and delivery of services. Experience in this area will inform future reform plans.
32. The authorities were keen to change the role of the government in the real economy. Their overall objective was to enhance regulatory capacity and let the private sector own and operate businesses. However, they recognized that this would take time and require significant capacity building within the government. In the meantime, they were in the process of estimating contingent liabilities of the government accumulating within SOEs and other quasigovernment bodies with a view to reduce and eventually eliminate them in the medium run. They also highlighted a potential exception, arguing that if an enterprise was making losses but still providing irreplaceable services to the tourism industry and generate positive externalities, then the government was ready to provide financial support to this enterprise.

\section{B. Ensuring an Adequate Level of Foreign Reserves}

\section{Background}

\section{Currently foreign reserves cover about} six months of Vanuatu's imports. The RBV aims to maintain foreign reserves above a minimum threshold of four months of import cover.

\section{Staff's Views}

34. While not a substitute for sound macroeconomic policy frameworks, foreign liquidity buffers can help smooth consumption in response to shocks. Moreover, in case of persistent shocks, these buffers can help create room for policies to adjust.

\footnotetext{
35. Vanuatu's foreign exchange reserves are currently adequate. Based on standard prudential norms, the current reserve coverage of six months of imports and 20 percent of GDP is comfortable and broadly in line with peers in the region (Box 3). However, reserve coverage is expected to gradually decline to four months of imports as the current account deficit remains large and the economy grows.
} 
36. Stress scenarios also suggest that the current level of reserves would provide sufficient time for the authorities to implement remedial measures. Four different low-probability but high-impact scenarios were considered: a sharp decline in tourism, termination of donor financing, continued decline in banks' net

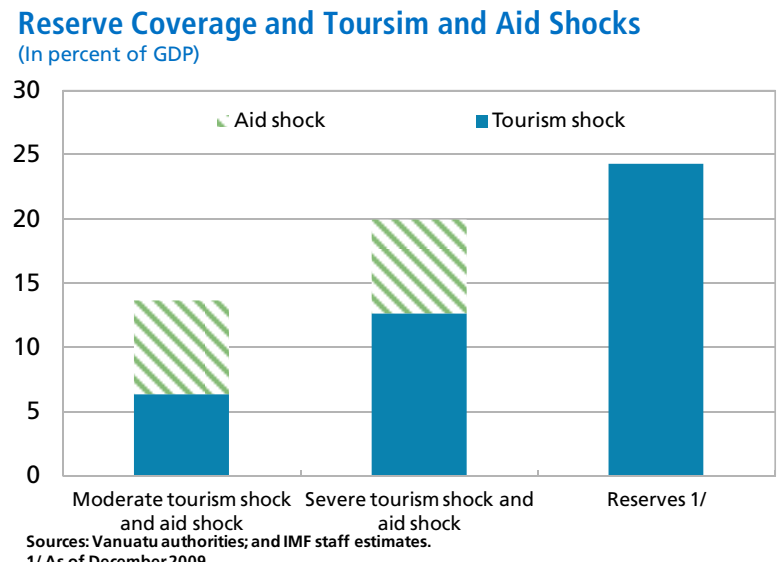
Sources: Vanuatu authorities; and IMF staff estimates.

foreign assets, and lower GDP growth rate owing to weak exports but continued strong domestic demand. Nevertheless, these scenarios also suggest that a significant decline in reserves would sharply

\section{Strengthening Financial Stability}

\section{Background}

38. Vanuatu's banking sector is stable. Banks are well capitalized (CAR was 30 percent in September 2010), liquid (the ratio of liquid assets to total assets and to demand deposits, were, respectively, 16 percent and 73 percent), and profitable (ROE was 5 percent). Banks' aggregate non-performing loan ratio has been declining increase the vulnerability of the economy to shocks. Therefore, to maintain the current buffer, reserves need to gradually increase in the medium term at a rate commensurate with the growth of external flows.

\section{The Authorities' Views}

\section{The authorities agreed with the staff} assessment. They considered reserves to be adequate, provided they remain above four months of imports. They expressed concern about the dependency of the reserves on foreign aid flows and the fact that the economy cannot generate sufficient foreign funds to be self-sustained. They were also concerned that a shift in the growth pattern away from exports to domestic demand could increase the size of imports to an unmanageable size and deplete the reserves in the medium term.

steadily in the last five years, but remains high at 5.9 percent.

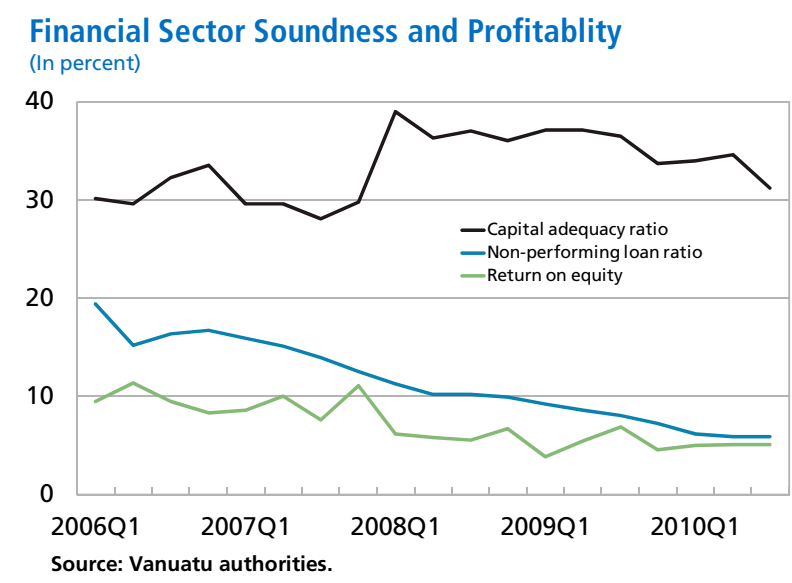


Box 3 Reserve Adequacy ${ }^{1}$

Vanuatu's foreign exchange reserves are adequate, according to both standard prudential measures and sensitivity analysis to exogenous shocks.

\section{Reserve coverage appears appropriate according to standard prudential metrics: \\ - Reserves relative to imports. Reserves have remained comfortable at five-six months of imports in recent years. This high ratio has created a comfortable policy space for the authorities to rapidly respond to unforeseen declines in export receipts.}

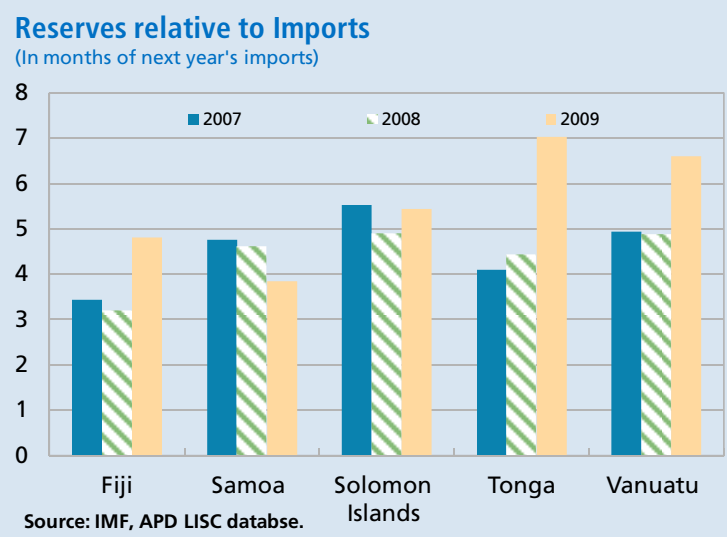

- Reserves relative to broad money. Reserves are around 25 percent of broad money, suggesting that the RBV has the ability to meet large requests for foreign currencies in the unlikely event of capital flight, with residents switching from the vatu to foreign currencies. The ratio, however, is lowest among peers in the region because Vanuatu's economy is more monetized.

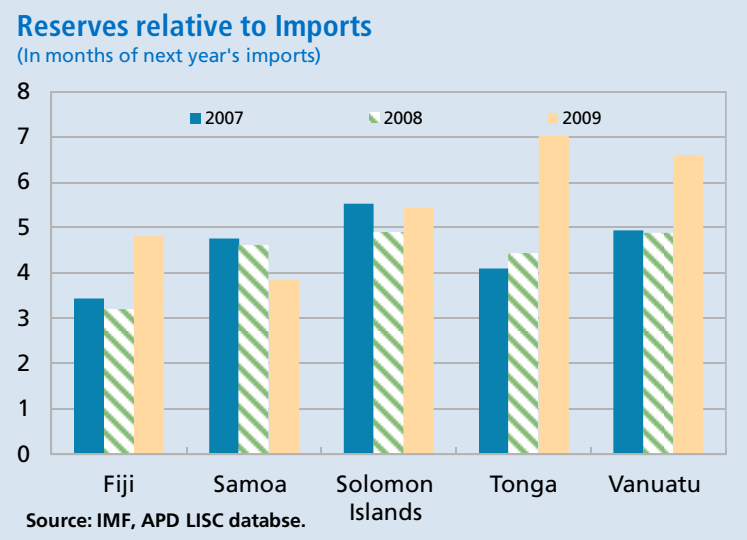

- Reserves relative to GDP. Reserves have been around 20 percent of GDP in recent years, in line with peers in the region. This suggests that reserves provide a comfortable cushion against economy-wide shocks.

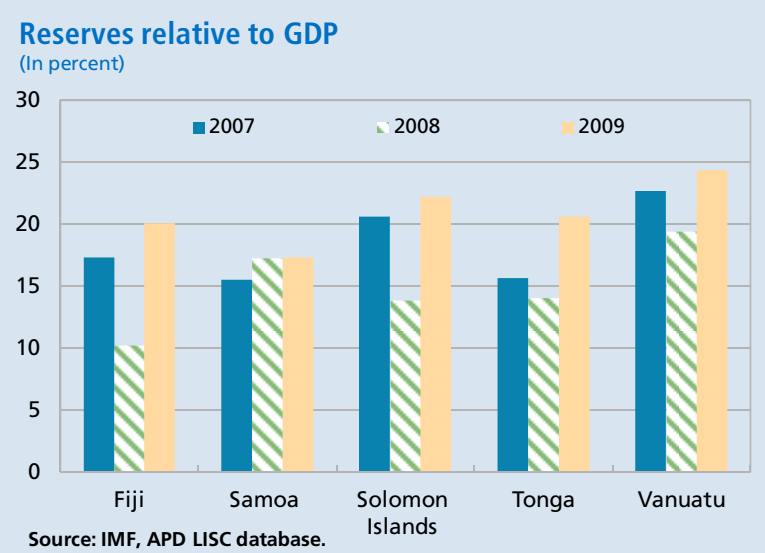

An alternative way to assess reserve adequacy is to consider low-probability but high-impact events and their implications on foreign exchange reserves. We consider four scenarios:

- A large shock to tourism. If significant disturbances occur in the region, Vanuatu's tourism sector could be severely affected. If tourism receipts decline by 40 percent, reserves would last more than two years.

- Simultaneous shocks to tourism and foreign aid. Shocks may occur simultaneously, especially if they originate from the same source. Concurrent with a sharp decline in tourism, if foreign aid dries up, foreign exchange reserves would last a bit longer than a year.

- Continuous decline in banks' net foreign assets. Banks' net foreign assets have eroded in recent quarters, reflecting borrowing from abroad to lend domestically and provision of foreign exchange to depositors who withdrew foreign exchange deposits. If this trend continues, banks will eventually run out of foreign exchange and official reserves will have to be used to make payments abroad. Net foreign assets of the entire banking system-including official reserveswould be depleted in about two years.

- Only domestic-sector led growth. If policies were reoriented to support domestic demand only, export receipts would begin to weaken and the potential growth rate would decline. In this scenario, reserves would shrink gradually and be depleted in the medium term.

\footnotetext{
$\overline{{ }^{1} \text { Prepared by Joji Ide. }}$
} 
39. The Vanuatu National Provident Fund (VNPF) is an important player in the financial sector. Eight percent of wages and salaries are being accumulated in the fund and currently its size is about 18 percent of GDP. It deposits most of these funds in local banks, and given its size has significant impact on banks' liquidity.

\section{Staff's Views}

40. The authorities should remain vigilant against any deterioration of banks' asset quality. The rapid credit growth of around 30 percent $(y / y)$ in 2008-09 could translate into an increase in NPL ratios as economic growth moderates. The sharp increase in lending to households and foreign currency lending should also be carefully watched.

\section{The regulatory and the legal} framework should continue to be strengthened. Staff welcomes the authorities' recent decision to incorporate a capital charge for operational risk and to tighten capital and liquidity requirements. Additional measures, such as imposing liquidity requirements on foreign exchange liabilities and clarifying the criteria required for loans to be exempt for the lending limit could be considered, as the recent Pacific Financial Assistance Center TA missions recommended. Policy guidelines to banks on prudential requirements should be finalized as a matter of priority and internal capacity to identify and assess banking risks should be improved. Also, the supervisory and regulatory framework should cover the whole financial system, including micro lenders, without an exception. Staff stressed the need for the authorities to further implement the recommendations of the 2006 Asia Pacific Group mutual evaluation report in order to enhance Vanuatu's AML/CFT regime in the area of effective implementation, particularly in the context of the Financial Action Task Force's initiative towards jurisdictions with strategic AML/CFT deficiencies.

42. Supervision should be intrusive. This has emerged as one of the key lessons from the global financial crisis. On- and off-site monitoring should be stepped up, supported by additional training. The Vanuatu Agriculture Development Bank has recently been brought under banking supervision, and the RBV should fully use its supervisory powers to ensure that the bank lends prudently. Close cooperation between the RBV and the VNPF in managing liquidity in the system is mutually beneficial and necessary for the stability of the overall financial system, given the dominant size of the VNPF in managing savings in Vanuatu.

\section{Offshore banks pose potential risks.}

These entities have opaque governing structures and liquidity problems or outright bankruptcies could have an important adverse reputational impact on Vanuatu. The RBV should exercise full oversight over these entities. Given that these banks create few jobs in Vanuatu and are not important sources of fiscal income, consideration should be given to further reducing the number of such banks with a view to eliminating them in the medium term.

44. Vanuatu should establish a bank resolution mechanism. A legal mechanism that will facilitate the resolution of weak banks in an 
orderly fashion is needed. Public funds should not be borne first by the owners and creditors, and any shortfall covered by the industry itself.

\section{The Authorities' Views}

45. The authorities broadly agreed with staff's assessment of the banking system. They thought that while overall NPLs would decline, NPLs in some areas, including personal loans, could increase moderately in the wake of the recent surge in lending. They noted that the banks were already in the process of raising their provisioning for NPLs. They considered that there was ample liquidity in the system, but its distribution was not even. They were monitoring the developments closely and stood ready to provide liquidity against appropriate collateral.

\section{A number of measures are being taken} to further boost the resilience of the system. The RBV had raised the capital-asset ratio from 8 percent to 12 percent this year, and all banks comfortably met this new regulatory requirement. In light of the increase in foreign exchange lending, the authorities were also considering imposing prudential regulations on the size of foreign be used in such an event; instead, the cost should

exchange loans relative to foreign assets. The RBV conducted regular on-site inspections focusing on not only credit risk management and operational risk management but also AMLCFT compliance. Regarding off-shore banks, the authorities explained that their numbers had declined from more than 100 to low single digits in three years and their role in the local economy was small, limiting risks to Vanuatu.

\section{The authorities explained that they} were making continuous efforts to strengthen the RBV's regulatory and supervisory capacity. The RBV has strengthened its cooperation with the Financial Intelligence Unit, which has the mandate to combat money laundering, financing of terrorism and other financial and economic crimes. Insurance supervision was moved from the Financial Services Commission to the RBV in late 2009. Although the supervision department at the RBV was restructured to accommodate the insurance supervision unit, lack of sufficiently trained staff remained a constraint for adequate supervision. More generally, the authorities acknowledged that their efforts were hampered by severe shortage in staffing in key areas. They welcomed Fund's and international community's assistance in building capacity and adopting international best practice in Vanuatu.

\section{STAFF APPRAISAL}

48. Economic activity is gradually rebounding, and inflation is picking up. Strengthening external and domestic demand is expected to raise the GDP growth rate to
33/4 percent this year and higher in 2012. Two key downside risks are slower-than-expected growth in tourism and delays in large investment projects. The surge in global commodity prices is likely to create 
persistent pressures on inflation and on the external accounts.

49. The authorities' appropriate macroeconomic policies were instrumental in this recovery. In 2010, fiscal policy was correctly balanced between stimulating the economy and maintaining fiscal sustainability. Accommodative monetary policy supported much needed investment.

50. Fiscal policy should be carefully couched to continue to support nascent recovery while making progress in fiscal consolidation. The 2011 budget target for expenditure is appropriate and the authorities should make every effort to meet it. Should revenue fall short of the budget target owing to slower growth, this should be tolerated. Next year, as the economy absorbs the full impact of investments initiated this year and growth solidifies, the authorities should aim for a broadly balanced budget, which will restore the fiscal space needed for future shocks.

51. The authorities should begin tightening monetary policy in response to rising inflationary pressures. The current accommodative stance should be gradually unwound and the excess liquidity in the banking system should be drained. The RBV should pay particular attention to any systemic risk arising from strong growth in lending to households and foreign exchange-denominated lending, and impose additional prudential measures if needed.
52. The authorities should not resist depreciation pressures on the vatu. Even though official reserves are stable, the decline in the net foreign assets of the banks suggests that there is more demand for foreign currency than supply. Should the pressure on Vanuatu's external accounts persist, the appropriate policy would be to allow the vatu to depreciate and adjust monetary policy to take into account rising prices of imported goods. Delays will likely worsen the cost of adjustment.

53. The authorities should continue to strengthen fiscal buffers to safeguard Vanuatu's hard-earned fiscal soundness. The budget structure should be improved by mobilizing revenue and reducing the rigidity on the expenditure side. In this regard, the authorities' efforts to improve revenue collection are commendable. In addition, the authorities could consider other means to mobilize revenue, including introducing income tax in the medium term. The large wage bill should be reduced as a matter of priority, and SOE efficiency and accountability should be improved to reduce the drain on the budget.

\section{Vanuatu should safeguard its external} buffers. Currently, official foreign exchange reserves are adequate. The authorities should remain vigilant against pressures that would significantly lower foreign reserves and continue to gradually build up reserves to maintain good coverage of external flows.

55. Vanuatu's banking sector is stable. To maintain financial stability, bank supervision should be intrusive. The RBV should exercise to the fullest 
extent its supervisory powers over the whole financial system and step up its on- and off-site supervision. The regulatory framework and supervisory staff skills should continue to be strengthened, with the help of the international community.

56. It is recommended that the next Article IV consultation take place on the 24-month cycle. 


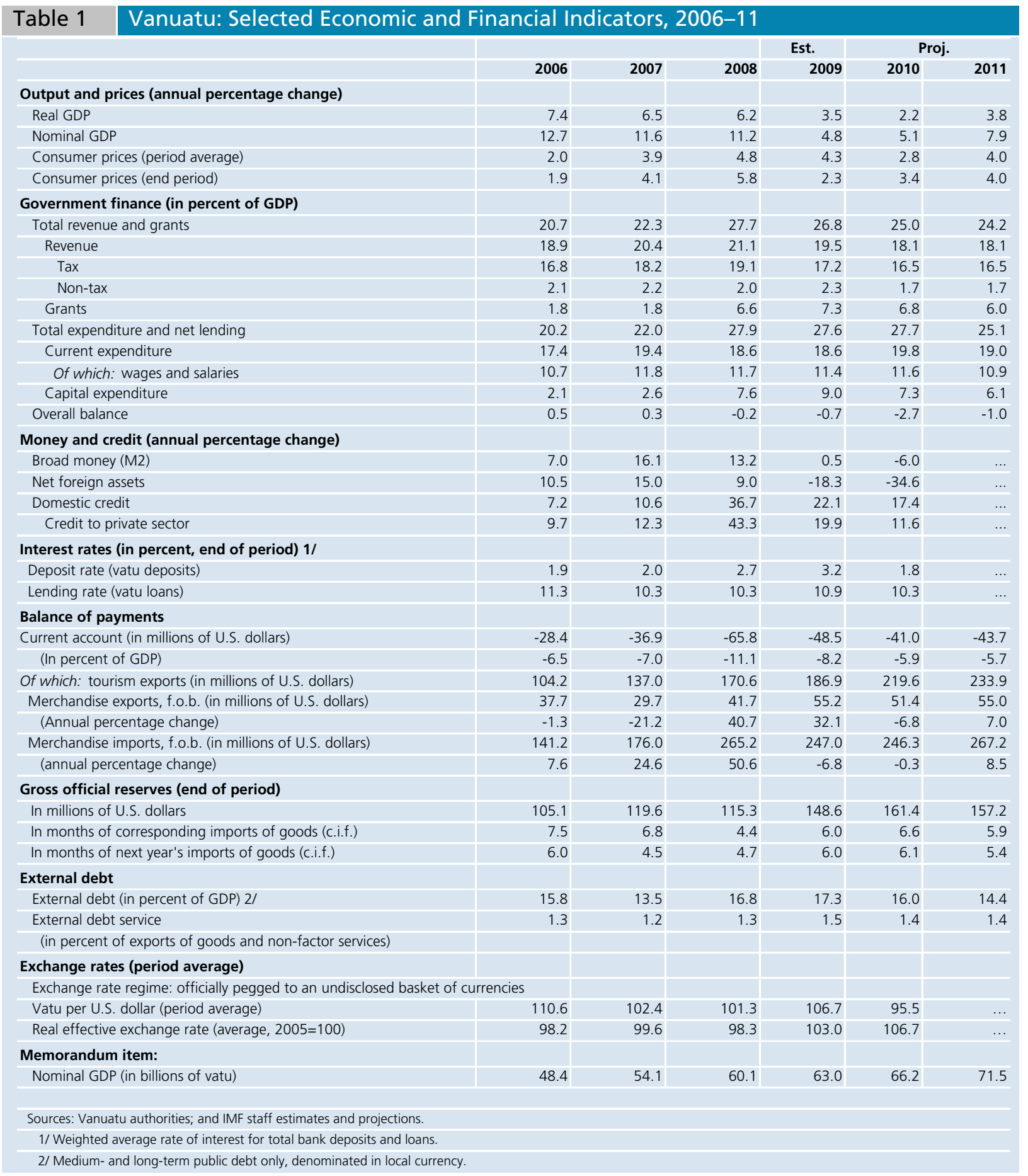




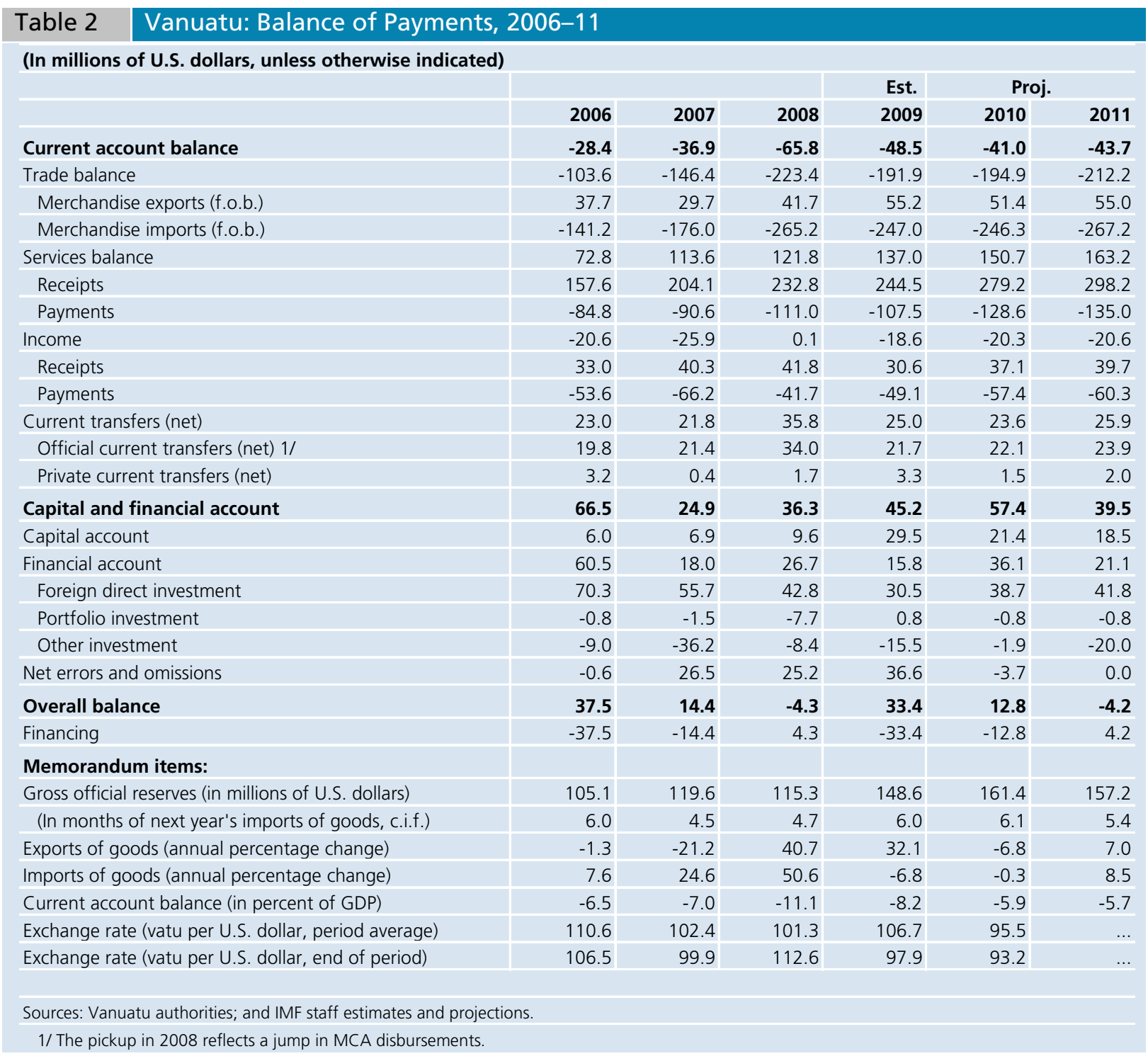




\begin{tabular}{|c|c|c|c|c|c|c|c|c|}
\hline Table 3 & \multicolumn{8}{|c|}{ Vanuatu: Central Government Fiscal Operations, 2006-11 } \\
\hline \multicolumn{9}{|c|}{ (In percent of GDP, unless otherwise indicated) } \\
\hline & & & & & Est. & Proj. & Budget & Proj. \\
\hline & & 2006 & 2007 & 2008 & 2009 & 2010 & \multicolumn{2}{|l|}{2011} \\
\hline \multicolumn{2}{|c|}{ Total revenue and grants } & 20.7 & 22.3 & 27.7 & 26.8 & 25.0 & 24.4 & 24.2 \\
\hline \multicolumn{2}{|c|}{ Revenue } & 18.9 & 20.4 & 21.1 & 19.5 & 18.1 & 18.3 & 18.1 \\
\hline \multicolumn{2}{|l|}{$\operatorname{Tax} 1 /$} & 16.8 & 18.2 & 19.1 & 17.2 & 16.5 & 16.5 & 16.5 \\
\hline \multicolumn{2}{|c|}{ Taxes on properties } & 0.4 & 0.9 & 1.1 & 0.7 & 0.7 & 0.7 & 0.7 \\
\hline \multicolumn{2}{|c|}{ Goods and services } & 10.8 & 10.8 & 11.5 & 10.2 & 11.7 & 12.0 & 11.7 \\
\hline \multicolumn{2}{|c|}{ International trade } & 5.5 & 6.3 & 6.4 & 6.2 & 4.0 & 3.8 & 4.0 \\
\hline \multicolumn{2}{|c|}{ Non tax } & 2.1 & 2.2 & 2.0 & 2.3 & 1.7 & 1.9 & 1.7 \\
\hline \multicolumn{2}{|c|}{ Capital revenue } & 0.0 & 0.0 & 0.0 & 0.0 & 0.0 & 0.0 & 0.0 \\
\hline \multicolumn{2}{|c|}{ Grants 2/ } & 1.8 & 1.8 & 6.6 & 7.3 & 6.8 & 6.0 & 6.0 \\
\hline \multicolumn{2}{|c|}{ Total expenditure and net lending } & 20.2 & 22.0 & 27.9 & 27.6 & 27.7 & 25.1 & 25.1 \\
\hline \multicolumn{2}{|c|}{ Total expenditure } & 19.5 & 22.0 & 26.2 & 27.6 & 27.1 & 25.1 & 25.1 \\
\hline \multicolumn{2}{|c|}{ Current expenditure } & 17.4 & 19.4 & 18.6 & 18.6 & 19.8 & 19.0 & 19.0 \\
\hline \multicolumn{9}{|c|}{ Of which: } \\
\hline \multicolumn{2}{|c|}{ Wages and salaries } & 10.7 & 11.8 & 11.7 & 11.4 & 11.6 & 10.9 & 10.9 \\
\hline \multicolumn{2}{|c|}{ Purchases of goods and services } & 3.3 & 4.4 & 3.6 & 3.5 & 4.4 & 3.8 & 3.8 \\
\hline \multicolumn{2}{|c|}{ Interest payments } & 0.7 & 0.6 & 0.6 & 0.5 & 0.5 & 0.7 & 0.7 \\
\hline \multicolumn{2}{|c|}{ Transfers } & 2.2 & 2.1 & 2.2 & 2.4 & 2.4 & 2.9 & 2.9 \\
\hline \multicolumn{2}{|c|}{ Capital expenditure } & 2.1 & 2.6 & 7.6 & 9.0 & 7.3 & 6.1 & 6.1 \\
\hline \multicolumn{2}{|c|}{ Primary balance } & 1.2 & 0.9 & 0.4 & -0.2 & -2.2 & -0.1 & -0.3 \\
\hline \multicolumn{2}{|c|}{ Overall balance } & 0.5 & 0.3 & -0.2 & -0.7 & -2.7 & -0.7 & -1.0 \\
\hline \multicolumn{2}{|c|}{ Financing } & -0.5 & -0.3 & 0.2 & 0.7 & 2.7 & 0.7 & 1.0 \\
\hline \multicolumn{2}{|c|}{ Foreign financing (net) } & -0.4 & -0.4 & 2.4 & 1.2 & -0.4 & -0.5 & -0.5 \\
\hline \multicolumn{2}{|c|}{ Concessional borrowing } & -0.4 & -0.4 & 2.4 & 1.2 & -0.4 & -0.5 & -0.5 \\
\hline Commer & al borrowing & 0.0 & 0.0 & 0.0 & 0.0 & 0.0 & 0.0 & 0.0 \\
\hline Domestic & nancing (net) & -0.1 & 0.1 & -2.1 & -0.5 & 3.2 & 1.2 & 1.4 \\
\hline Domesti & market borrowing (net) & -0.5 & -0.2 & -0.7 & -0.2 & 1.2 & 1.2 & 1.4 \\
\hline Other $\mathrm{dc}$ & estic borrowing (net) & 0.4 & 0.3 & -1.5 & -0.3 & 2.0 & 0.0 & 0.0 \\
\hline Memoranc & m items: & & & & & & & \\
\hline Public debt & & 22.2 & 19.1 & 21.1 & 21.2 & 21.0 & 20.2 & 20.4 \\
\hline Domestic & & 6.4 & 5.5 & 4.3 & 3.9 & 5.0 & 5.8 & 6.0 \\
\hline External & & 15.8 & 13.5 & 16.8 & 17.3 & 16.0 & 14.4 & 14.4 \\
\hline Sources: Van & atu authorities; and IMF staff $\Theta$ & jections. & & & & & & \\
\hline 1/ Net of $t$ & rebate for import duties paid & & & & & & & \\
\hline 2/ Cash g & & & & & & & & \\
\hline
\end{tabular}




\begin{tabular}{|c|c|c|c|c|c|c|c|}
\hline \multirow[t]{2}{*}{ Table 4} & \multicolumn{2}{|c|}{ 2004-10 } & \multirow[b]{2}{*}{2006} & \multirow[b]{2}{*}{2007} & \multirow[b]{2}{*}{2008} & \multirow[b]{2}{*}{2009} & \multirow[b]{2}{*}{2010} \\
\hline & 2004 & 2005 & & & & & \\
\hline & \multicolumn{7}{|c|}{ (In millions of vatu; end of period) } \\
\hline Net foreign assets & 27,575 & 29,488 & 32,596 & 37,497 & 40,878 & 33,409 & 21,864 \\
\hline Monetary Authorities 1/ & 6,413 & 7,351 & 10,964 & 11,623 & 12,814 & 11,600 & 12,321 \\
\hline Commercial banks & 21,162 & 22,138 & 21,632 & 25,874 & 28,063 & 21,809 & 9,543 \\
\hline Net domestic assets & 10,572 & 13,074 & 12,959 & 15,411 & 18,995 & 26,737 & 34,676 \\
\hline Domestic credit & 16,943 & 18,423 & 19,748 & 21,834 & 29,843 & 36,435 & 42,786 \\
\hline Claims on government (net) & 955 & -162 & -697 & $-1,110$ & $-3,010$ & $-2,971$ & $-1,183$ \\
\hline Claims on municipalities & 6 & 13 & 13 & 17 & 13 & 16 & 16 \\
\hline Claims on non-financial public enterprises & 29 & 27 & 81 & 67 & 72 & 107 & 95 \\
\hline Claims on private sector & 15,953 & 18,545 & 20,351 & 22,860 & 32,768 & 39,283 & 43,857 \\
\hline Other items (net) & -6371 & -5349 & $-6,789$ & $-6,422$ & $-10,848$ & $-9,699$ & $-8,110$ \\
\hline Total broad money & 38,148 & 42,562 & 45,555 & 52,908 & 59,873 & 60,146 & 56,540 \\
\hline Narrow money & 6,557 & 7,425 & 8,969 & 10,781 & 11,447 & 11,542 & 14,036 \\
\hline Currency outside banks & 2,490 & 2,691 & 3,156 & 3,570 & 3,756 & 3,917 & 4,542 \\
\hline Demand deposits & 4,067 & 4,734 & 5,813 & 7,211 & 7,691 & 7,625 & 9,494 \\
\hline Quasi-money & 31,590 & 35,138 & 36,586 & 42,128 & 48,425 & 48,604 & 42,504 \\
\hline Time and savings deposits & 9,261 & 11,313 & 13,049 & 15,384 & 19,617 & 21,379 & 23,162 \\
\hline Demand deposits in foreign currency & 6,176 & 6,615 & 6,798 & 7,716 & 8,565 & 10,907 & 8,098 \\
\hline \multirow[t]{2}{*}{ Time and savings deposits in foreign currency } & 16,153 & 17,210 & 16,739 & 19,027 & 20,244 & 16,318 & 11,245 \\
\hline & \multicolumn{7}{|c|}{ (Annual percentage change) } \\
\hline Net foreign assets & 11.7 & 6.9 & 10.5 & 15.0 & 9.0 & -18.3 & -34.6 \\
\hline Net domestic assets & 5.2 & 23.7 & -0.9 & 18.9 & 23.3 & 40.8 & 29.7 \\
\hline Domestic credit & 7.9 & 8.7 & 7.2 & 10.6 & 36.7 & 22.1 & 17.4 \\
\hline Private sector credit & 9.6 & 16.3 & 9.7 & 12.3 & 43.3 & 19.9 & 11.6 \\
\hline Total broad money & 9.8 & 11.6 & 7.0 & 16.1 & 13.2 & 0.5 & -6.0 \\
\hline Narrow money & 11.7 & 13.2 & 20.8 & 20.2 & 6.2 & 0.8 & 21.6 \\
\hline Quasi-money & 9.5 & 11.2 & 4.1 & 15.1 & 14.9 & 0.4 & -12.6 \\
\hline Vatu broad money & 15.6 & 18.5 & 17.5 & 18.8 & 18.7 & 6.0 & 13.0 \\
\hline Foreign currency deposits & 6.1 & 6.7 & -1.2 & 13.6 & 7.7 & -5.5 & -29.0 \\
\hline \multicolumn{8}{|l|}{ Memoranda items: } \\
\hline Foreign currency deposits (in millions of vatu) & 22,329 & 23,825 & 23,536 & 26,744 & 28,809 & 27,225 & 19,342 \\
\hline (In millions of U.S. dollars) & 210 & 212 & 221 & 268 & 256 & 278 & 208 \\
\hline (In percent of total deposits) & 62.6 & 59.8 & 55.5 & 54.2 & 51.3 & 48.4 & 37.2 \\
\hline \multicolumn{8}{|l|}{ Velocity } \\
\hline Narrow money & 6.2 & 5.8 & 5.4 & 5.0 & 5.3 & 5.5 & 4.7 \\
\hline Vatu broad money & 2.6 & 2.3 & 2.2 & 2.1 & 1.9 & 1.9 & 1.8 \\
\hline Total broad money & 1.1 & 1.0 & 1.1 & 1.0 & 1.0 & 1.0 & 1.2 \\
\hline Credit to private sector (in percent of GDP) & 39.2 & 43.2 & 42.0 & 42.3 & 54.5 & 62.3 & 66.2 \\
\hline
\end{tabular}




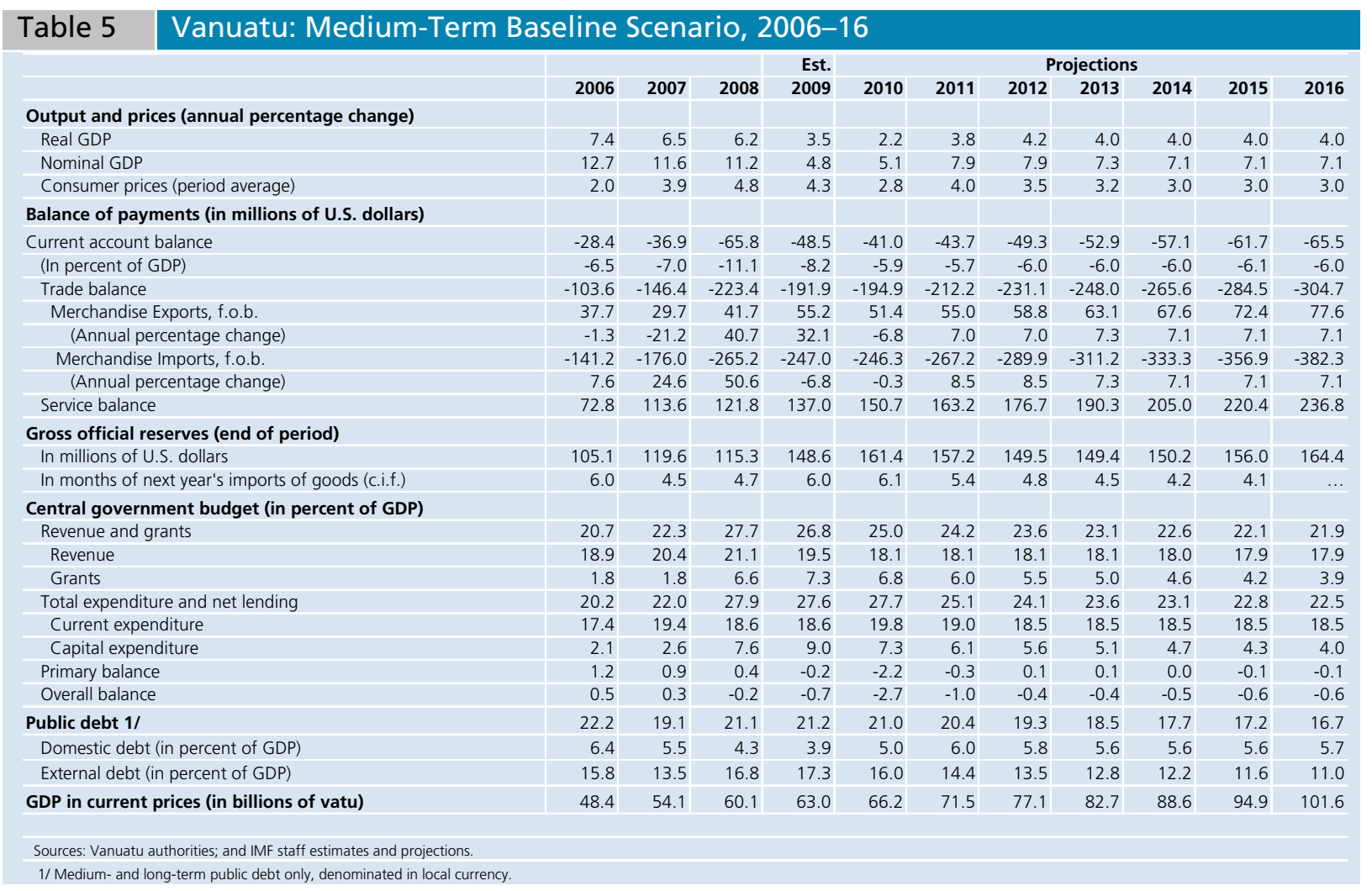




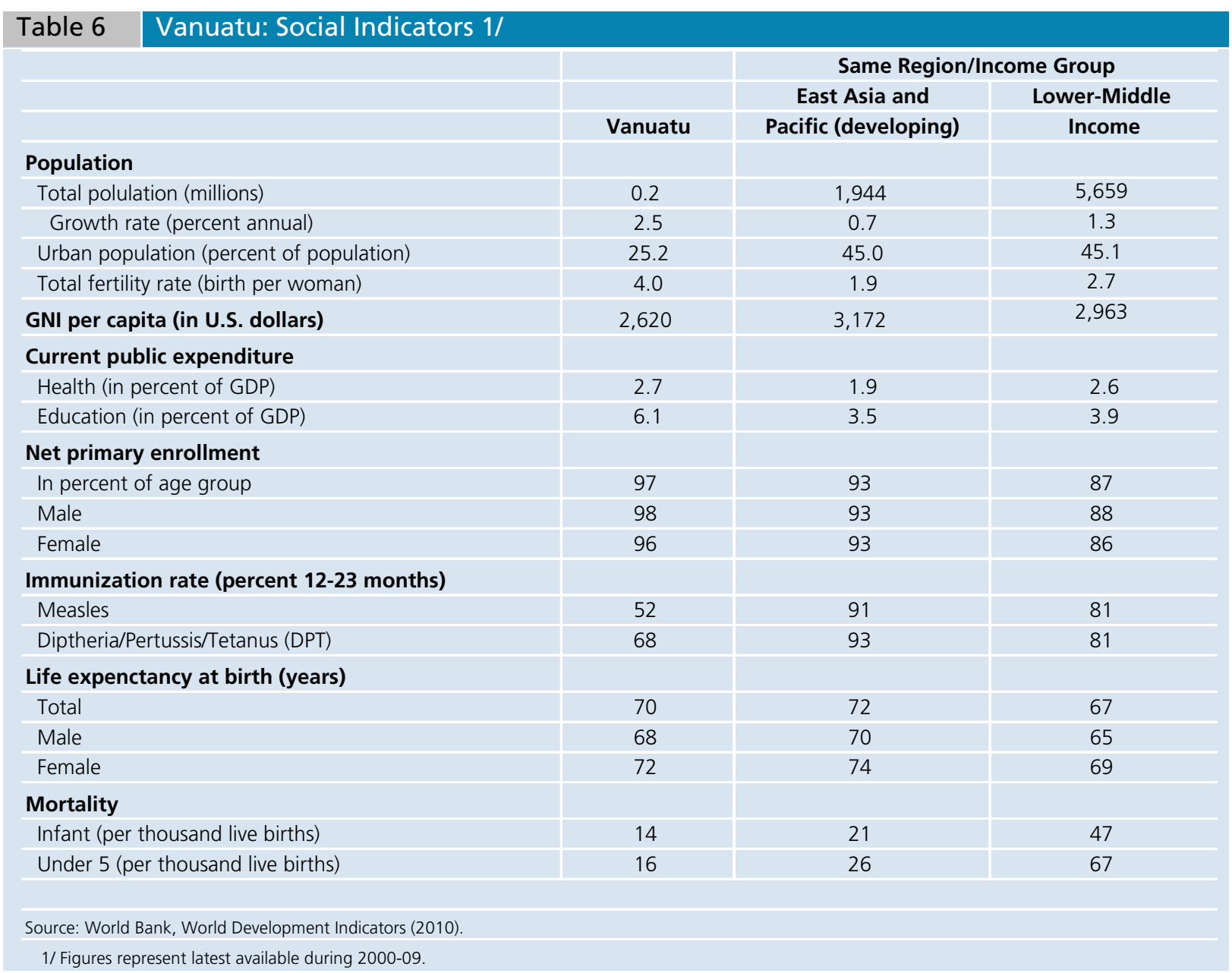




\begin{tabular}{|c|c|c|c|c|c|}
\hline & 1990 & 1995 & 2000 & 2005 & 2009 \\
\hline \multicolumn{6}{|l|}{ Goal 1: Eradicate extreme poverty and hunger } \\
\hline Employment to population ratio, $15+$, total (\%) & .. & .. & .. & .. & \\
\hline Employment to population ratio, ages $15-24$, total (\%) & .. & .. & .. & ... & \\
\hline GDP per person employed (constant 1990 PPP \$) & .. & .. & .. & .. & .. \\
\hline Income share held by lowest $20 \%$ & .. & .. & .. & .. & .. \\
\hline Malnutrition prevalence, weight for age (\% of children under 5) & .. & .. & .. & .. & .. \\
\hline Poverty gap at $\$ 1.25$ a day (PPP) (\%) & .. &.. & .. & .. & ... \\
\hline Poverty headcount ratio at $\$ 1.25$ a day (PPP) (\% of population) & .. & .. & .. & .. & .. \\
\hline Vulnerable employment, total (\% of total employment) & .. &.. & .. & .. & .. \\
\hline \multicolumn{6}{|l|}{ Goal 2: Achieve universal primary education } \\
\hline Literacy rate, youth female (\% of females ages $15-24$ ) & .. & .. & .. & 92 & 94 \\
\hline Literacy rate, youth male (\% of males ages $15-24$ ) & .. & .. & .. & 92 & 94 \\
\hline Persistence to last grade of primary, total (\% of cohort) & .. & .. & 69 & 73 & \\
\hline Primary completion rate, total ( $\%$ of relevant age group) & 83 & .. & 86 & 86 & 79 \\
\hline Total enrollment, primary (\% net) & .. & .. & 95 & 98 & 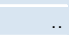 \\
\hline \multicolumn{6}{|l|}{ Goal 3: Promote gender equality and empower women } \\
\hline Proportion of seats held by women in national parliaments (\%) & 4 & .. & 0 & 4 & 4 \\
\hline Ratio of female to male primary enrollment $(\%)$ & 98 & .. & 98 & 97 & 96 \\
\hline Ratio of female to male secondary enrollment (\%) & 80 & .. & 114 & 86 & \\
\hline Ratio of female to male tertiary enrollment (\%) & .. & .. & 57 & 59 & \\
\hline Share of women employed in the non-agricultural sector (\% of total nonagricultural employment) & .. & .. & .. & 37.9 & 37.8 \\
\hline \multicolumn{6}{|l|}{ Goal 4: Reduce child mortality } \\
\hline Immunization, measles ( $\%$ of children ages $12-23$ months) & 66 & 60 & 61 & 53 & 52 \\
\hline Mortality rate, infant (per 1,000 live births) & 33 & 27 & 21 & 17 & 14 \\
\hline Mortality rate, under-5 (per 1,000) & 40 & 32 & 25 & 20 & 16 \\
\hline \multicolumn{6}{|l|}{ Goal 5: Improve maternal health } \\
\hline Adolescent fertility rate (births per 1,000 women ages 15-19) & .. & .. & 58 & 51 & 46 \\
\hline Births attended by skilled health staff (\% of total) & .. & 89 & 88 & 74 & 74 \\
\hline Contraceptive prevalence (\% of women ages $15-49)$ & 15 & .. & 28 & 38 & 38 \\
\hline Maternal mortality ratio (modeled estimate, per 100,000 live births) & .. & .. & .. & .. & \\
\hline Pregnant women receiving prenatal care (\%) & .. & .. & .. & 84 & 84 \\
\hline Unmet need for contraception (\% of married women ages 15-49) & .. & .. & .. & .. & .. \\
\hline \multicolumn{6}{|l|}{ Goal 6: Combat HIV/AIDS, malaria, and other diseases } \\
\hline Children with fever receiving antimalarial drugs (\% of children under age 5 with fever) & .. & .. & .. & 36 & 36 \\
\hline Condom use, population ages $15-24$, female ( $\%$ of females ages $15-24$ ) & .. & .. &.. & .. & .. \\
\hline Condom use, population ages $15-24$, male (\% of males ages $15-24$ ) & .. & .. & .. & .. & .. \\
\hline Incidence of tuberculosis (per 100,000 people) & 140 & 120 & 98 & 83 & 74 \\
\hline Prevalence of HIV, female (\% ages $15-24)$ & .. & .. & .. & .. & .. \\
\hline Prevalence of HIV, male (\% ages $15-24)$ & .. & .. & .. & .. & \\
\hline Prevalence of HIV, total (\% of population ages $15-49$ ) & .. & .. & .. & .. & \\
\hline Tuberculosis case detection rate (all forms) & 67 & 39 & 82 & 43 & 59 \\
\hline \multicolumn{6}{|l|}{ Goal 7: Ensure environmental sustainability } \\
\hline CO2 emissions ( $\mathrm{kg}$ per PPP $\$$ of GDP) & 0 & 0 & 0 & 0 & 0 \\
\hline CO2 emissions (metric tons per capita) & 0 & 0 & 0 & 0 & 0 \\
\hline Forest area (\% of land area) & 36.1 & 36.1 & 36.1 & 36.1 & 36.1 \\
\hline Improved sanitation facilities (\% of population with access) & .. & 34 & 41 & 47 & 52 \\
\hline Improved water source (\% of population with access) & 57 & 64 & 72 & 78 & 83 \\
\hline Marine protected areas (\% of total surface area) & .. & .. & .. & .. & 0 \\
\hline Terrestrial protected areas (\% of total surface area) & .. & .. & .. & .. & 4 \\
\hline \multicolumn{6}{|l|}{ Goal 8: Develop a global partnership for development } \\
\hline Net ODA received per capita (current US\$) & 331 & 265 & 241 & 182 & 392 \\
\hline Debt service (PPG and IMF only, \% of exports, excluding workers' remittances) & 2 & 1 & 1 & 1 & 1 \\
\hline Internet users (per 100 people) & 0.0 & 0.1 & 2.1 & 5.1 & 7.3 \\
\hline Mobile cellular subscriptions (per 100 people) & 0 & 0 & 0 & 6 & 15 \\
\hline Telephone lines (per 100 people) & 2 & 2 & 3 & 3 & 4 \\
\hline \multicolumn{6}{|l|}{ Other } \\
\hline Fertility rate, total (births per woman) & 5 & 5 & 4 & 4 & 4 \\
\hline GNI per capita, Atlas method (current US\$) & 1180 & 1240 & 1440 & 1780 & 2620 \\
\hline GNI, Atlas method (current US\$) (billions) & 0.2 & 0.2 & 0.3 & 0.4 & 0.6 \\
\hline Gross capital formation (\% of GDP) & 33.2 & 22.6 & 19.3 & 19.5 & 24.1 \\
\hline Life expectancy at birth, total (years) & 63 & 66 & 68 & 69 & 70 \\
\hline Literacy rate, adult total (\% of people ages 15 and above) & .. & 69 & .. & 78 & 81 \\
\hline Population, total (billions) & 0 & 0 & 0 & 0 & 0 \\
\hline Trade (\% of GDP) & 120.0 & 98.0 & 84.4 & 94.0 & 98.0 \\
\hline
\end{tabular}




\section{INTERNATIONAL MONETARY FUND}

\section{VANUATU}

STAFF REPORT FOR THE 2011 ARTICLE IV

April 8, 2011

\section{CONSULTATION-INFORMATIONAL ANNEX}

$\begin{array}{ll}\text { Prepared By } & \text { The Asia and Pacific Department } \\ \text { (In Consultation with Other Departments) }\end{array}$

\section{CONTENTS}

I. FUND RELATIONS 2

II. RELATIONS WITH THE PACIFIC FINANCIAL TECHNICAL ASSISTANCE CENTER_ 4

III. BANK-FUND COUNTRY TEAM CONSULTATIONS 6

IV. RELATIONS WITH THE ASIAN DEVELOPMENT BANK 8

V. STATISTICAL ISSUES 11 


\section{ANNEX I. VANUATU: FUND RELATIONS}

(As of February 28, 2011)

\section{Membership Status}

Joined: September 28, 1981; Article VIII

\begin{tabular}{|l|r|r|}
\hline \multirow{2}{*}{ General Resources Account } \\
& SDR Million & Percent Quota \\
\hline Quota & 17.00 & 100.00 \\
\hline Fund holdings of currency & 14.51 & 85.33 \\
\hline Reserve position in Fund & 2.50 & 14.68 \\
\hline
\end{tabular}

SDR Department

\begin{tabular}{|l|r|r|}
\hline & SDR Million & Percent Allocation \\
\hline Net cumulative allocation & 16.27 & 100.00 \\
\hline Holdings & 1.54 & 9.45 \\
\hline
\end{tabular}

Outstanding Purchases and Loans

None

Financial Arrangements

None

\section{Projected Obligations to Fund ${ }^{1}$}

(SDR Million; based on existing use of resources and present holdings of SDRs)

\begin{tabular}{|c|c|c|c|c|c|}
\hline & \multicolumn{5}{|c|}{ Forthcoming } \\
\hline & 2011 & 2012 & 2013 & 2014 & 2015 \\
\hline \multicolumn{6}{|l|}{ Principal } \\
\hline Charges/interest & 0.05 & 0.06 & 0.06 & 0.06 & 0.06 \\
\hline Total & 0.05 & 0.06 & 0.06 & 0.06 & 0.06 \\
\hline
\end{tabular}

\section{Exchange Arrangements}

Since 1988, Vanuatu has officially maintained an adjustable peg exchange rate arrangement. Currently, the exchange rate of the vatu is linked to a transactions weighted (trade and tourism receipts) basket of currencies. The weights and composition of the basket, which are not publicly disclosed, are adjusted periodically. The Reserve Bank of Vanuatu (RBV) quotes daily buying and selling rates for the vatu against the U.S., Australian, and New Zealand dollars; the euro; the U.K. pound; and the Japanese yen. The rate in terms of the U.S. dollar as of January 31, 2010 was VT 93.88 per U.S. dollar. The de facto classification is "other managed," as the composite weights are not disclosed and cannot be confirmed.

Vanuatu has accepted the obligations of Article VIII, Sections 2, 3, and 4, and maintains an exchange system that is free of restrictions on payments and transfers for current international transactions.

\section{Article IV Consultations}

The last Article IV consultation discussions with the authorities were held in Port Vila during February 2009. The Executive Board discussed the staff report and concluded the consultation on May 11, 2009. 


\section{OFC Assessments}

The most recent Offshore Financial Center Module II Assessment, conducted by MFD was concluded in May 2006.

\section{Technical Assistance from Headquarters} (2000-present)

LEG, MCM, PFTAC, and STA have provided technical assistance on anti-money laundering banking supervision and regulation, reserve management, tax and fiscal accounts, tax administration and policy, balance of payments, and national accounts.

\section{Resident Representative}

None 


\section{ANNEX II. VANUATU: RELATIONS WITH THE PACIFIC FINANCIAL TECHNICAL ASSISTANCE CENTER (PFTAC) ${ }^{1}$}

Since 2008, the Center's assistance to Vanuatu has included 20 advisory missions. In addition, Vanuatu has sent officials to the Center's regional seminars, workshops, and training courses and has attached a revenue official to a PFTAC mission.

\section{Financial Sector Supervision}

Recent assistance activities have primarily been devoted to strengthening the capacity of the Reserve Bank of Vanuatu (RBV) to supervise and regulate its domestic and offshore banking institutions. The PFTAC Financial Sector Supervision Advisor visited the RBV in April 2009 to review and provide recommendations for strengthening prudential guidelines (regulations) and review the adequacy of prudential reporting requirements for banking institutions. A followup visit was conducted in May 2010 to assess the status of proposed revisions to prudential guidelines and to provide training to supervision staff in on-site examination and off-site monitoring of banking institutions. In response to identified weaknesses in the capacity of the RBV supervision staff to properly examine and assess banking risks, a third visit was conducted

\footnotetext{
${ }^{1}$ PFTAC in Suva, Fiji is a multi-donor technical assistance institution, financed by the IMF, AsDB, AusAID, NZODA, and, until 2001, by the UNDP, with the IMF as Executing Agency. The Centre's aim is to build skills and institutional capacity for effective economic and financial management that can be sustained at the national level. Member countries are: Cook Islands, Federated States of Micronesia, Fiji, Kiribati, Marshall Islands, Nauru, Niue, Palau, Papua New Guinea, Samoa, Solomon Islands, Tokelau, Tonga, Tuvalu, and Vanuatu.
}

in January 2011 to provide training and assistance in conducting an on-site examination of an offshore bank. At the request of the RBV, a follow-up visit will be conducted in late 2011 to assist the authorities in finalizing revisions to prudential returns and to provide training and assistance to the supervision staff in off-site monitoring and analysis and the preparation of quarterly analysis reports.

\section{Public Financial Management}

AusAid has funded an extensive technical assistance program in budget management. PFTAC has complemented that assistance through advice on prioritization and sequencing of needed reforms, and, in 2003, by training of staff on moving budget reporting to a GFS basis (see below). PFTAC has also been providing advice and assistance through a peripatetic advisor on macroeconomic forecasting and analysis. It has also provided training for line ministry officials on Public Financial Management and costing of projects

\section{Tax Administration and Policy}

There is a potential loss of revenue arising from regional trade agreements and arrangements 
(PICTA and PACER). In response, PFTAC has provided a range of assistance to the authorities to minimize the impact of any revenue loss. PFTAC assistance has included development of a compliance improvement strategy and plan, incountry training to improve skills and techniques in audit, taxpayer services, debt collection and return management and development of a longer-term corporate strategy. On the policy side PFTAC has provided assistance to analyze and consider the possible introduction of additional taxes.

\section{Economic Statistics}

Technical assistance provided in the context of the GDDS/PFTAC project for Pacific Island countries resulted in Vanuatu producing quarterly balance of payments and international investment position statistics consistent with the BPM5 and ongoing assistance is helping with the transition to BPM6. During 2010, PFTAC trained staff and developed methodology for presenting government finance statistics on the basis of the 2001GFS Manual and for integration of GFS classifications with the budget and accounting systems. Data based on the new standards is nearing completion. PFTAC provided peer review of national accounts compilation in 2005 and 2006. PFTAC missions were undertaken in 2008 and 2009 to review source data and developed methodology to produce GDP by expenditure approach. 


\section{ANNEX III. VANUATU: BANK-FUND COUNTRY TEAM CONSULTATIONS}

As of September 28, 2010

\section{The Bank and Fund country teams for} Vanuatu, led by Mr. Suri and Mr. Eskesen, respectively, had a phone conversation on September 27, 2010, to exchange views on key macroeconomic prospects, identify macro-critical structural reforms, and coordinate the two teams' work for the period September 2010-August 2011. ${ }^{1}$

2. The teams agreed on the main macroeconomic issues for Vanuatu. These are the near-term growth outlook, appropriate fiscal and monetary policies over the near term, maintaining the sound fiscal course over the medium term, and addressing structural issues to raise economic growth over the medium term. More specifically:

- Near-term growth outlook

- Key determinants of growth: Prospects for tourism and the role played by donorfinanced construction-related activities

- Fiscal policy

- Appropriate fiscal stance in 2011 and 2012

- Reorientation of spending to enhance growth and revenue raising efforts,

\footnotetext{
${ }^{1}$ Other participating country team members included Mr. Joji Ide (IMF).
}

including the introduction of income taxation over the medium term

- Efforts to strengthen the medium-term fiscal framework, including through the enhancement of multi-year budgeting

- Monetary policy

- Timing and pace of exit from accommodative policies

- Effectiveness of monetary policy in managing economic activity

- Financial policy

- The implications of the rapid credit growth for bank soundness

- Continuing efforts to strengthen financial supervision and regulation

- Structural issues

- Improving basic infrastructure

- Strengthening the investment climate

- Enhancing education and labor market flexibility

\section{Based on this shared assessment, the} teams identified three areas as macrocritical, in view of their central role in achieving a sound macro-financial policy framework and sustained growth: (i) continuing efforts to strengthen the medium-term fiscal framework and explore options to generate more revenues to counter the decline in collections due to trade liberalization and to mobilize more funds to finance social and physical infrastructures, 
including through the introduction of income taxation; (ii) continuing efforts to safeguard financial stability by further strengthening financial supervision and regulation; and (iii) improving basic infrastructure such as roads and ports to raise economic growth. Table III.1 details the specific activities planned by the two country teams over the period September 2010August 2011, along with their expected deliveries.

\section{The teams have the following} requests for information and collaboration from their counterparts:

- The Fund team requests to be kept informed of progress in various projects and analytical work undertaken by the Bank in order to use resources efficiently and avoid work overlaps.
- The Bank team requests the Fund to make available to the Bank its latest macroeconomic assessment and macroeconomic data from time to time as inputs to the Bank's lending and non-lending operations.

5. No disagreement among the two teams emerged on either the key issues, challenges, or on the division of tasks to tackle these. It was agreed that further details on collaboration, as necessary, will be agreed at the technical level as work progresses.

\begin{tabular}{|c|c|c|}
\hline Table III.1 & \multicolumn{2}{|c|}{$\begin{array}{l}\text { Vanuatu: Bank and Fund planned activities in macro-critical structural } \\
\text { reform areas, September 2010-August } 2011\end{array}$} \\
\hline & Products & Expected Delivery Date \\
\hline $\begin{array}{l}\text { Bank Work } \\
\text { Program }\end{array}$ & $\begin{array}{l}\text { - Support to Utilities Regulatory Agency to retender } \\
\text { the electricity concession in Luganville, and } \\
\text { undertake a review of the current tariff structure } \\
\text { - Support to regulatory reform in telecoms }\end{array}$ & $\begin{array}{l}\text { - Ongoing } \\
\text { - Ongoing }\end{array}$ \\
\hline \multirow[t]{3}{*}{$\begin{array}{l}\text { Fund Work } \\
\text { Program }\end{array}$} & $\begin{array}{l}\text { - Article IV Policy Consultation Note (internal) } \\
\text { - Article IV Staff Report and Board Meeting (public), } \\
\text { including a joint-DSA with the Bank }\end{array}$ & $\begin{array}{l}\text { - } \quad \text { February } 2011 \\
\text { - } \quad \text { April } 2011\end{array}$ \\
\hline & $\begin{array}{l}\text { Possible analytical work for the Article IV mission } \\
\circ \text { Scope for tax reform } \\
\circ \text { Effectiveness of monetary policy } \\
\circ \quad \text { Financial sector soundness }\end{array}$ & - $\quad$ April 2011 \\
\hline & $\begin{array}{l}\text { - Technical Assistance: Government Finance } \\
\text { Statistics (organized by PFTAC) } \\
\text { Technical Assistance: Compliance Improvement } \\
\text { Strategy Update (organized by PFTAC) }\end{array}$ & $\begin{array}{l}\text { - } \quad \text { September } 2010 \\
\text { - } \quad \text { Late } 2010\end{array}$ \\
\hline
\end{tabular}




\section{ANNEX IV. VANUATU: RELATIONS WITH THE ASIAN DEVELOPMENT BANK}

As of January 31, 2011

\section{Operational Strategy}

Asian Development Bank's (AsDB) Country Partnership Strategy for 2010-14 is aligned with the government's poverty reduction strategy and aims to assist the government to address constraints in (i) transport-by providing support for improved connectivity to markets and social services; (ii) urban development-by improving access to sanitation and drainage facilities and improve urban infrastructure with a particular focus on Port Vila; and (iii) energy_-by supporting greater energy efficiency, rural electrification, and renewable energy sources. Consistent with the government's strategy of fostering private-sectorled growth, AsDB also focuses on improving the enabling environment for the private sector through updating the legal and regulatory environment, better access to finance, and the reform and restructuring of state-owned enterprises (SOEs).

Subject to the annual country performance assessment exercise, AsDB envisions support from 2011 to 2012 of about $\$ 20$ million in loans from the Asian Development Fund as well as $\$ 1$ million per annum in technical assistance (TA) grant support. To leverage AsDB's impact and reduce borrowing costs, cofinancing opportunities will be pursued with other development partners.

\section{Lending Trends/ADF Grants/Portfolio Status}

Since joining AsDB in 1981, 9 loans have been provided to Vanuatu for a total amount of $\$ 51.25$ million and 57 TA projects for $\$ 18.22$ million. More than 50 percent of the loans were for infrastructure rehabilitation and more than 40 percent of the TA was for institutional support and capacity building. Due to a previous non-borrowing policy, there are no loan projects currently in the portfolio and 4 active TA projects amounting to $\$ 2.95$ million. The following are ongoing activities: TA 7023VAN: Expanding Access to Financial Services; TA 7288-VAN: Interisland Shipping Support Project; TA 7345-VAN: Port Vila Urban Development Project; and TA 7588-VAN: State-Owned Enterprise Rationalization Program. AsDB has also been active in improving the business regulatory environment in Vanuatu through TA 4856-VAN: Vanuatu Financial Services Commission, Institutional and Legal Reforms. This TA is now closed but continued support is being provided under RETA-6353: Pacific Private Sector Development Initiative I and RETA-7340: Pacific Private Sector Development Initiative II.

\section{Private Sector Development. AsDB's country} strategy in Vanuatu aims for rapid, inclusive, and private sector-led economic growth. AsDB's capacity development and advisory support 
focuses on (i) improving the business regulatory environment; (ii) expanding access to finance; and (iii) reforming SOEs. The Private Sector Operations Department will play a growing role in AsDB's country operations in Vanuatu. Such operations are being examined on their individual merits, though there are prospects for assisting the finance sector.

\section{- Improving the business regulatory} environment. Recent AsDB assistance has been focused on drafting a new Companies Act, a new Insolvency Act and a new Trustee Act. Advisory support will continue for the implementation of these new laws and for establishing an upgraded companies' registry.

- Expanding Access to Financial Services. AsDB provides ongoing assistance for improving access to finance opportunities in Vanuatu. The expansion of the telecom network technological advances and the entry of Digicel into the market has increased the variety of technological options available to provide access to financial services in rural areas, including the use of mobile phones, the equipping of mobile National Bank of Vanuatu (NBV) officers with wireless handheld point of sale units for electronic transactions and bringing NBV branches in rural areas permanently online.

- State-Owned Enterprise Program. SOE reform is central to the improved economic governance supported through AusAID's Governance for Growth Program, and the Partnership for Development signed in 2010 between the Governments of Australia and Vanuatu. AsDB approved a stand-alone TA in 2010 to support the Government's SOE reform efforts, and awaits engagement from the Ministry of Finance in order to develop a detailed work plan and mobilize required expertise. The reform of the Government's SOEs will be focused on assisting the Government to improve the governance, transparency, and efficiency of the SOEs. This could also include closure or divestiture as appropriate.

Interisland Shipping Support Project. AsDB has cooperated closely with New Zealand to prepare a package of investments and technical assistance to improve interisland shipping services, capacity, and regulation. The main outcomes of the proposed project would include (i) better access to markets and social services in the outer island target areas by 2014; (ii) stronger safety regulations and more compliance; and (iii) better shipping infrastructure. At the time of proposal finalization in October 2010, the Government requested that the proposal be put on hold to seek additional grant finance. The current proposal offers financing of about 40 percent grants and 60 percent concessional lending. AsDB stands ready to finalize the proposal and work toward implementation as soon as the government is ready to proceed.

Port Vila Urban Development Project. AsDB's support for urban development will contribute to social development by improving access to sustainable basic services in urban areas. AsDB, in 
partnership with AusAID and other donors, including through the Pacific Regional Infrastructure Facility, will provide assistance focused on urban planning and the provision of affordable, sustainable, and effective sanitation and drainage services to the residents of Port Vila and its surrounds, particularly to those living in informal settlements. Specific results of the proposed assistance will include (i) preparation of robust planning, legislative and policy documents for implementation in cooperation with the Government, (ii) preparation of an integrated storm water drainage and sanitation master plan; (iii) institutional strengthening and capacity development; and (iv) provision of high priority drainage and sanitation infrastructure.

Regional Cooperation Initiatives. Regional support will continue to be provided for renewable energy and energy efficiency, private sector development, management of civil aviation through the Pacific Aviation Safety Office, public sector financial management, institutional capacity for economic reform, strategic infrastructure, and sustainable management of the natural resource base through the Coral Triangle Initiative. Under the Pacific Alliance for
Sustainability, funded by the Global Environment Facility, AsDB is helping to build climate change adaptation capacity through regional TA aimed at strengthening management of coastal and marine resources. The regional TA for Statistical Capacity Building in the Asia and Pacific Region will continue. AsDB will continue to support Vanuatu's participation in regional forums. AsDB will continue to work closely with the Pacific Islands Forum in a variety of areas, including on economic monitoring and formulation and implementation of economic policy.

\section{AsDB-World Bank joint Development Coordination Office}

AsDB is strengthening its assistance to Vanuatu through closer collaboration with the government and other development partners. An AsDB-World Bank joint Development Coordination Office was launched in June 2010 in Port Vila. The shared field presence will support AsDB's responsiveness to the development needs of Vanuatu and will support aid coordination and aid effectiveness. 


\section{ANNEX V. VANUATU: STATISTICAL ISSUES}

As of January 31, 2011

\section{Assessment of Data Adequacy for Surveillance}

General: Data provision has some shortcomings, but is broadly adequate for surveillance. In particular, data on national accounts, government finance, and external sector statistics need to be further improved.

National Accounts: While there have been improvements in methodology and the development of additional data sources, expenditure-based GDP estimates are not yet available. Also, data are compiled only on an annual basis. Constant price GDP estimates still use 1983 as the base year, although work on rebasing the estimates to 2006 are underway.

Price statistics: The CPI weights are based on 1998 household surveys, and only cover the two urban centers of Port Vila and Luganville. The CPI basket does not reflect the recent structural changes in the consumption basket, for example telecommunication prices and related utilities.

Government finance statistics: Budget classification is broadly consistent with the 1986 GFSM. Government operations data include all central government agencies. However, they exclude public enterprises and operations of provincial governments and the two municipalities. The operations of the budget are recorded on a cash plus invoice basis.

Monetary statistics: The Reserve Bank of Vanuatu (RBV) reports monthly monetary data, including the accounts of the monetary authorities, commercial banks, and interest rates in its monthly bulletin posted on its website. The RBV also publishes a quarterly report with the coverage of wider financial data including fiscal transactions and financial soundness indicators (e.g., amount of nonperforming loans and earnings).

External sector statistics: Quarterly and annual balance of payments data are compiled according to The Balance of Payment Manual, Fifth Edition. Trade data have been compiled using customs declaration forms collected from the two shipping ports of entries, Port Vila and Santo. Imported items by air are also captured, but imported goods and services through the post office have not been captured. Data on capital account also need further improvements. Errors and omissions remain quite large.

\section{Data Standards and Quality}

Participant in the General Data Dissemination System (GDDS) since April 2004.

No data ROSC is available.

\section{Reporting to STA}

Exchange rate and reserves data are only available through August 2010. Monthly monetary statistics data have been reported through December 2010. Annual balance of payments data have been published through 2007. Quarterly consumer price data have available through Q2 2010. Imports and exports annual trade figures are available only through 2007. Both the trade and price data are gathered from other sources; no data are sent by the authorities. Annual GFS data through 1999 have been reported for publication in the GFS Yearbook, using the 1986 GFS format. No subannual fiscal data have been reported for publication in International Financial Statistics since 2001. 


\begin{tabular}{|c|c|c|c|c|c|}
\hline \multirow[t]{2}{*}{ Vanuatu: Table of Com } & non Indicator & Required f & urveillance & \multirow[b]{2}{*}{$\begin{array}{l}\text { Frequency } \\
\text { of } \\
\text { Reporting }\end{array}$} & \multirow[b]{2}{*}{$\begin{array}{l}\text { Frequency of } \\
\text { Publication }\end{array}$} \\
\hline & $\begin{array}{l}\text { Date of Latest } \\
\text { Observation }\end{array}$ & $\begin{array}{c}\text { Date } \\
\text { Received }\end{array}$ & $\begin{array}{l}\text { Frequency of } \\
\text { Data }\end{array}$ & & \\
\hline Exchange Rates & Feb. 2011 & Feb. 2011 & D & $\mathrm{D}$ & M \\
\hline $\begin{array}{l}\text { International Reserve Assets and Reserve } \\
\text { Liabilities of the Monetary Authorities }^{1}\end{array}$ & Dec. 2010 & Mar. 2011 & M & M & M \\
\hline Reserve/Base Money & Dec. 2010 & Mar. 2011 & M & M & M \\
\hline Broad Money & Dec. 2010 & Mar. 2011 & M & M & M \\
\hline Central Bank Balance Sheet & Dec. 2010 & Mar. 2011 & M & M & M \\
\hline $\begin{array}{l}\text { Consolidated Balance Sheet of the Banking } \\
\text { System }\end{array}$ & Dec. 2010 & Mar. 2011 & M & M & M \\
\hline Interest Rates ${ }^{2}$ & Dec. 2010 & Mar. 2011 & M & M & M \\
\hline Consumer Price Index & Dec. 2010 & Jan. 2011 & Q & Q & Q \\
\hline $\begin{array}{l}\text { Revenue, Expenditure, Balance and Composition } \\
\text { of Financing }^{3} \text {-General Government }{ }^{4}\end{array}$ & NA & NA & NA & NA & NA \\
\hline $\begin{array}{l}\text { Revenue, Expenditure, Balance and Composition } \\
\text { of Financing }{ }^{3} \text {-Central Government }\end{array}$ & Dec. 2010 & Feb. 2011 & Q & Q & Q \\
\hline $\begin{array}{l}\text { Stocks of Central Government and Central } \\
\text { Government-Guaranteed Debt }{ }^{5}\end{array}$ & Dec. 2010 & Feb. 2011 & A & A & A \\
\hline External Current Account Balance & Dec. 2010 & Mar. 2011 & Q & Q & Q \\
\hline Exports and Imports of Goods and Services ${ }^{6}$ & Dec. 2010 & Mar. 2011 & Q & Q & Q \\
\hline GDP/GNP & 2009 & Jan. 2011 & A & 1 & 1 \\
\hline Gross External Debt & Dec. 2010 & Feb. 2011 & A & A & A \\
\hline International Investment Position ${ }^{7}$ & Dec. 2010 & Mar. 2011 & Q & Q & Q \\
\hline \multicolumn{6}{|c|}{$\begin{array}{l}\text { Any reserve assets that are pledged or otherwise encumbered should be specified separately. Also, data should comprise short-term } \\
\text { liabilities linked to a foreign currency, but settled by other means, as well as the notional values of financial derivatives to pay and to } \\
\text { receive foreign currency, including those linked to a foreign currency but settled by other means. }\end{array}$} \\
\hline \multicolumn{6}{|c|}{2 Both market-based and officially-determined, including discount rates, money market rates, rates on treasury bills, notes and bonds. } \\
\hline \multicolumn{6}{|c|}{3 Foreign, domestic bank, and domestic nonbank financing. } \\
\hline \multicolumn{6}{|c|}{$\begin{array}{l}{ }^{4} \text { The general government consists of the central government (budgetary funds, extra budgetary funds, and social security funds) and } \\
\text { state and local governments. }\end{array}$} \\
\hline \multicolumn{6}{|c|}{${ }^{5}$ Including currency and maturity composition. } \\
\hline \multicolumn{6}{|l|}{${ }^{6}$ Services data available on an annual basis. } \\
\hline
\end{tabular}




\section{INTERNATIONAL MONETARY FUND}

April 8, 2011

\section{VANUATU}

STAFF REPORT FOR THE 2011 ARTICLE IV

CONSULTATION-DEBT SUSTAINABILITY ANALYSIS

Approved By

Subir Lall and

Thomas Dorsey (IMF),

Jeffery D. Lewis and

Vikram Nehru (IDA)
Prepared by the staffs of the International Monetary Fund and the International Development Association

Vanuatu remains at a low risk of debt distress based on the Low-Income Country Debt Sustainability Assessment (LIC DSA). Vanuatu's overall public debt level is low and should remain manageable, provided the fiscal deficit is reduced substantially as planned from the 2010 level. The level of public debt distress may rise if potential GDP growth slows or large contingent liabilities materialize.

\footnotetext{
${ }^{1}$ This DSA was prepared jointly with the World Bank, in accordance with the Debt Sustainability Framework for low-income countries approved by the Executive Boards of the IMF and IDA. The debt data underlying this exercise were provided by the Vanuatu authorities.
} 


\section{A. Background}

1. In 2010, despite a sharp increase in the fiscal deficit, Vanuatu's public debt remained at a comfortable level of 20 percent of GDP. The deficit was domestically financed. Vanuatu's total external debt increased to 34 percent of GDP, reflecting higher external liabilities of local banks. Public and publicly guaranteed (PPG) external debt remained at around 15 percent of GDP. ${ }^{1}$

\section{The debt sustainability analysis is based} on the standard LIC DSA framework, ${ }^{2}$ and the baseline is built on the assumptions presented

in Box 1. The key assumptions are that the nearterm GDP growth will recover to 4 percent, the current account deficit will remain below 6 percent of GDP, the primary deficit will decline to close to zero over the long term, and grants will remain

\footnotetext{
${ }^{1}$ Due to data limitation, external liabilities of local banks are used as a proxy for total private external debt.

${ }^{2}$ See "Debt Sustainability in Low-Income Countries: Proposal for an Operational Framework and Policy Implications" (http://www.imf.org/external/np/pdr/sustain/2004/020304.pdf and IDA/SECM2004/0035, 2/3/04), "Debt Sustainability in LowIncome Countries: Further Considerations on an Operational Framework and Policy Implications" (http://www.imf.org/external/np/pdr/sustain/2004/091004.pdf and IDA/SECM2004/0629, 9/10/04), and reference to "Staff Guidance Note on the Application of the Joint Bank-Fund Debt Sustainability Framework for Low-Income Countries" (http://www.imf.org/external/np/pp/eng/2010/012210.pdf).
}

stable in the medium term and gradually decline as a share of GDP in the longer term.

\section{These assumptions are somewhat} different from the last DSA, because of the largerthan-expected increase in the fiscal deficit and a slowdown in output growth. In particular, this year the DSA assumes a balanced primary deficit over the long run, compared to a surplus of $1 / 2$ percent of GDP assumed in the last DSA, and long-term growth potential is assumed to be $1 / 2$ percentage point slower, closer to the historical average. The current DSA also assumes that the current account deficit will remain around the current level with the export base widening and investment in tourism-related infrastructure helping boost tourism gradually over the long term. 


\section{Key Macroeconomic Assumptions}

\begin{tabular}{|c|c|}
\hline \multicolumn{3}{|c|}{ Baseline } \\
\hline $\mathbf{2 0 1 0 - 2 0 1 5}$ & $\mathbf{2 0 1 6 - 2 0 3 0}$ \\
\hline 3.7 & 4.0 \\
\hline 7.3 & 7.3 \\
\hline-5.4 & -4.7 \\
\hline 5.7 & 3.0 \\
\hline 0.4 & 0.0 \\
\hline
\end{tabular}

\begin{tabular}{|c|c|c|}
\hline Historical & \multicolumn{2}{|c|}{ 2009 DSA Baseline } \\
\hline Average & $\mathbf{2 0 0 8 - 2 0 1 3}$ & $\mathbf{2 0 1 4 - 2 0 2 8}$ \\
\hline 3.5 & 4.4 & 4.5 \\
\hline 8.7 & 5.8 & 7.5 \\
\hline-4.9 & -5.7 & -7.2 \\
\hline 4.8 & 2.6 & 3.0 \\
\hline 0.5 & -1.1 & -0.4 \\
\hline
\end{tabular}

Real GDP growth (percent)

Growth of exports of goods and services (U.S. dollar terms)

Non-interest current account balance (in percent of GDP)

GDP deflator growth (U.S. dollar terms)

Primary deficit (in percent of GDP)

Real GDP growth is projected to average around 4 percent in the long term, significantly below the levels observed before the crisis, but somewhat higher than the longer-term historical average, assuming that infrastructure projects will elevate the long-term growth potential of Vanuatu.

- GDP deflator (in U.S. dollar terms) is projected to be around 53/4 percent over the period 2010-15 and 3 percent over the long term, which is below the upper limit of the Reserve Bank of Vanuatu's policy target band.

- Primary deficit is projected to decline to $1 / 4$ percent of GDP by 2012 and close to zero over the long term. This is because Vanuatu's fiscal responsibility law requires the government to maintain its debt at prudent levels and the 2011 budget already envisages a small primary deficit.

- The present of value of contingent liabilities is assumed to be 10 percent of GDP for the whole projection period, broadly in line with levels observed in the region.

- Foreign aid is projected to remain stable in Australian dollars over 2011-16 and gradually drop to below 1 percent of GDP over the long term as Vanuatu's per capita income level rises significantly.

- The current account deficit is expected to remain below 6 percent of GDP over the medium term, reflecting the relatively undiversified export base. Tourism remains the main source of foreign exchange earnings. Over the long term, as Vanuatu's economy matures the current account deficit is projected to decline to below 5 percent of GDP. The deficit is projected to be financed mostly by net FDI, and new external borrowings are assumed to grow gradually in the long run (around half a billion vatu during 2012-16 and double during 2017-30).

\section{B. External Debt Sustainability}

4. Under the baseline scenario, Vanuatu's external debt remains at a sustainable level.

Total and PPG external debt are projected to decline to 30 percent and 11 percent of GDP, respectively, in the medium term and further to 25 percent and 6 percent of GDP, respectively, over the long term. Other key indicators of sustainability-the present value of PPG external debt, the ratio of PPG debt service to exports, and the ratio of PPG debt service to revenue-all remain well below the indicative thresholds. The main reasons are (i) the fiscal deficit is expected to shrink; and (ii) the large trade deficit is expected to continue to be financed by foreign aid and FDI rather than debt-creating flows. 


\begin{tabular}{|c|r|r|r|}
\hline \begin{tabular}{|l|l|} 
Vanuatu: PPG External Debt Indicators \\
\hline
\end{tabular} & \multicolumn{1}{|c|}{ Indicative } \\
\hline Nhresholds 1/ & $\mathbf{2 0 0 9}$ & $\mathbf{2 0 1 0}$ \\
\hline NPV of PPG external debt & 40 & 14 & 13 \\
\hline In percent of GDP & 150 & 28 & 26 \\
\hline In percent of exports & 250 & 72 & 69 \\
\hline In percent of revenue & & & \\
\hline Debt service & 20 & 2 & 1 \\
\hline In percent of exports & 30 & 4 & 4 \\
\hline In percent of revenue & & & \\
\hline
\end{tabular}

1/ Represents LIC DSA indicative thresholds for Vanuatu that is classified as a medium performer under the World Bank's Country Policy Institutional Assessment.

5. Stress tests show that Vanuatu's external debt position is vulnerable to a slowdown in exports, although external sustainability is not threatened. A reduction in exports (of goods and services) value by $4 \frac{1}{2}$ percent consecutively during 2011-12, caused by, say, a larger-than-expected impact of the floods in Australia, would raise the present value of PPG

\section{Public Debt Sustainability}

7. The public sector DSA reinforces the conclusions of the external DSA. Under the baseline scenario, public sector debt is projected to remain below 20 percent of GDP and decline steadily over the medium and long term. All other indicators point in the same direction. However, if the primary deficit is kept at the 2010 level of 21/4 percent of GDP, then public debt and all related indicators would increase drastically. The present value of debtto-GDP ratio would reach around 30 percent in 2010 and continue to increase throughout the projection period.

\section{Stress tests indicate that vulnerabilities remain in contingent liabilities or a growth}

external debt to 61 percent of exports by next year, but the ratio would decline to around 20 percent over the long term.

\section{On the other hand, the alternative} scenario that is based on historical averages provides a more sanguine picture than the baseline. This is mainly because the trade deficit was smaller as a percent of GDP over the past decade. Therefore, if the current account deficit reverts back to historical levels, PPG external debt could shrink more quickly.

shock. The government may find itself in a position to take over the liabilities of a state-owned enterprise (SOE) or recapitalize a bank. There is no sufficient information to estimate such contingent liabilities with precision; therefore, a stress test is conducted with a 10-percent of GDP increase in other debtcreating flows, which is broadly in line with experiences in the region. The results suggest that the debt levels increase significantly and return to current levels only in the long run. If, on the other hand, GDP growth slows down permanently (by about 1 percentage point), the debt-to-GDP ratio rises steadily albeit at a quite slow pace. 


\section{Staff Assessment}

9. Vanuatu is at a low risk of debt distress, but medium-term vulnerabilities remain. External and public debt levels are low. To maintain fiscal and external debt levels at manageable levels, current plans to strengthen revenue and reduce wage bill need to be implemented. Also, the government needs to remain vigilant against contingent liabilities building up in the SOEs and the banking system, and ensure Vanuatu's growth potential remains strong. 


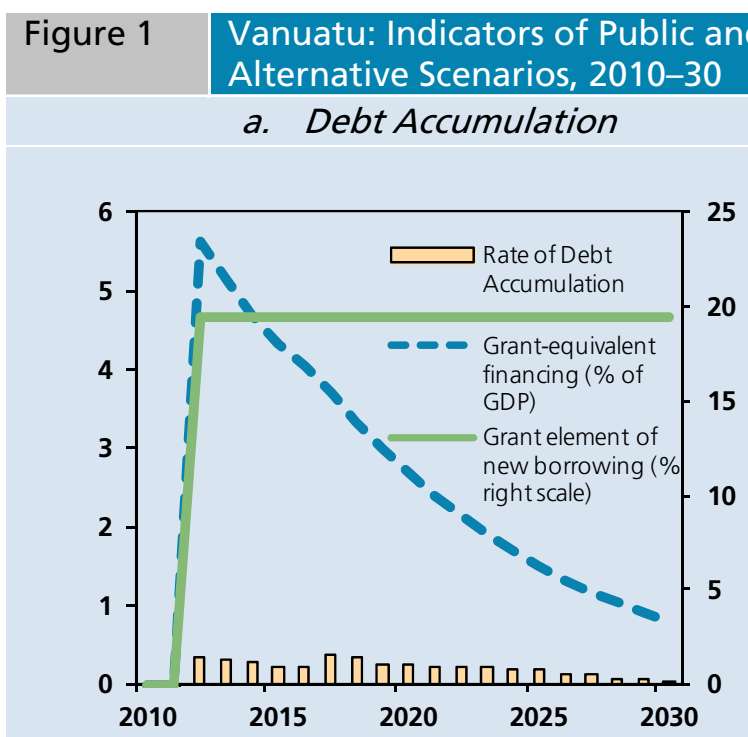

c. PV of debt-to-exports ratio

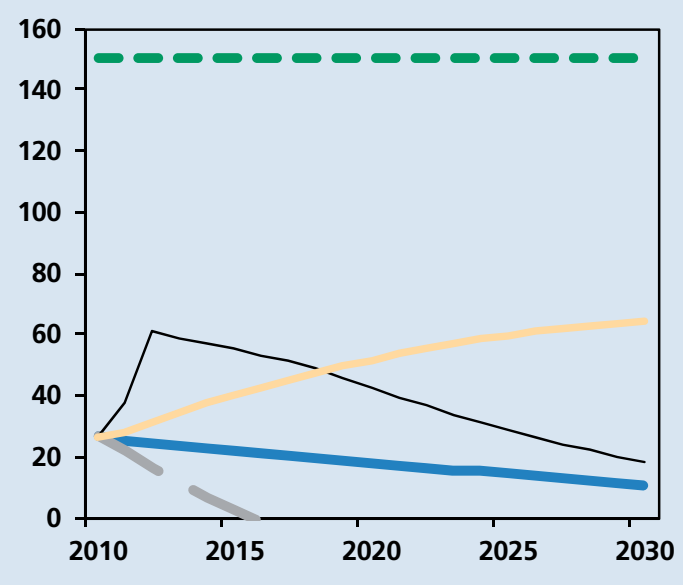

e. Debt service-to-exports ratio

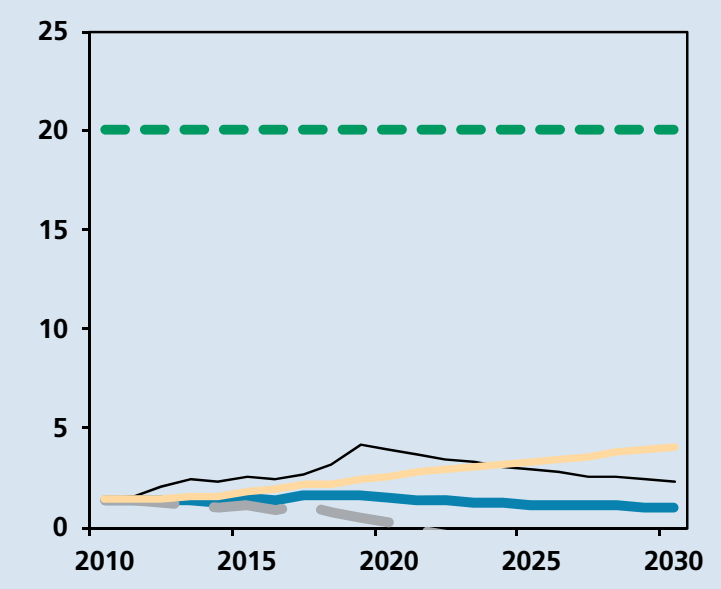

b. PV of debt-to GDP ratio

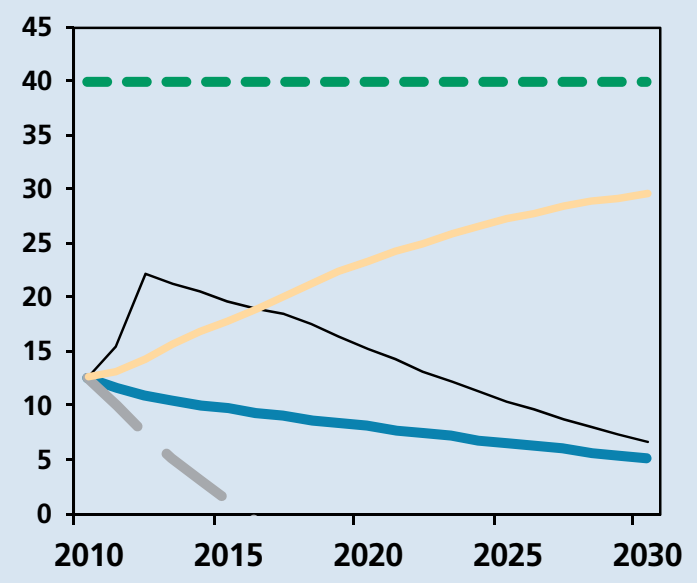

d. PV of debt-to-revenue ratio
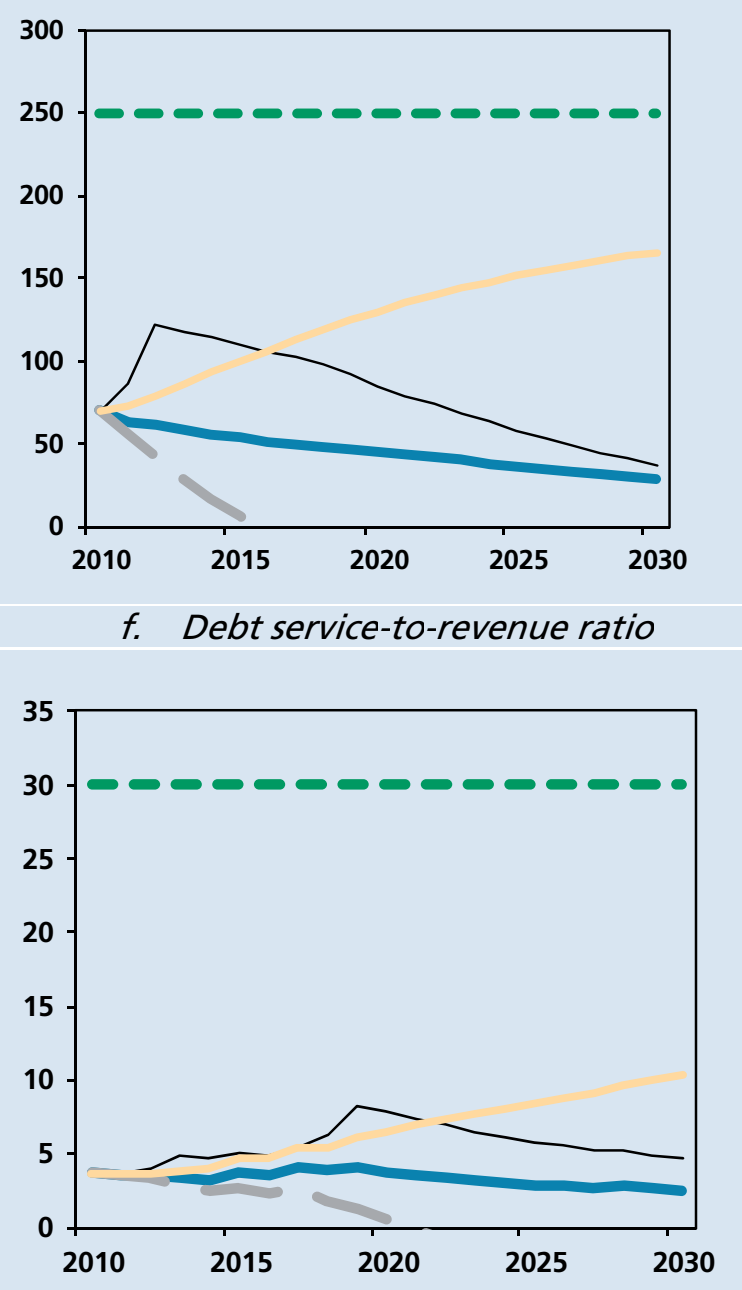

Baseline

Historical scenario

Exports - - Threshold

Fix primary balance

Sources: Vanuatu authorities; and IMF staff estimates and projections. 
Figure 2 Vanuatu: Indicators of Public Debt Under Alternative Scenarios, 2010-30 1/
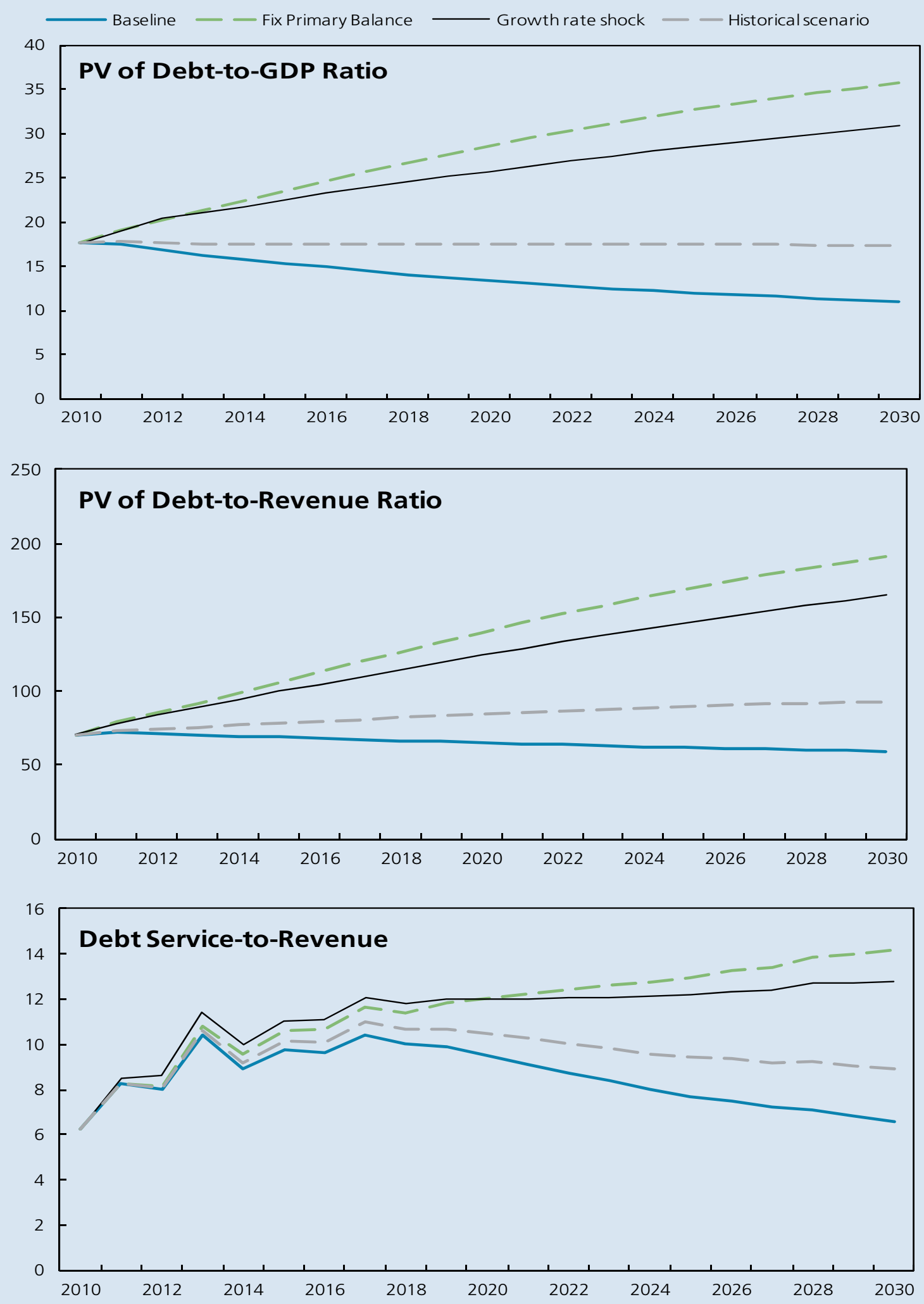

Sources: Vanuatu authorities; and IMF staff estimates and projections.

$1 /$ The growth rate shock is when real GDP growth is the historical average minus one standard deviation in 2011-12.

2/ Revenues are defined inclusive of grants. 
Table 1 External Debt Sustainability Framework, Baseline Scenario, 2007-30 1/

(In percent of GDP, unless otherwise indicated)

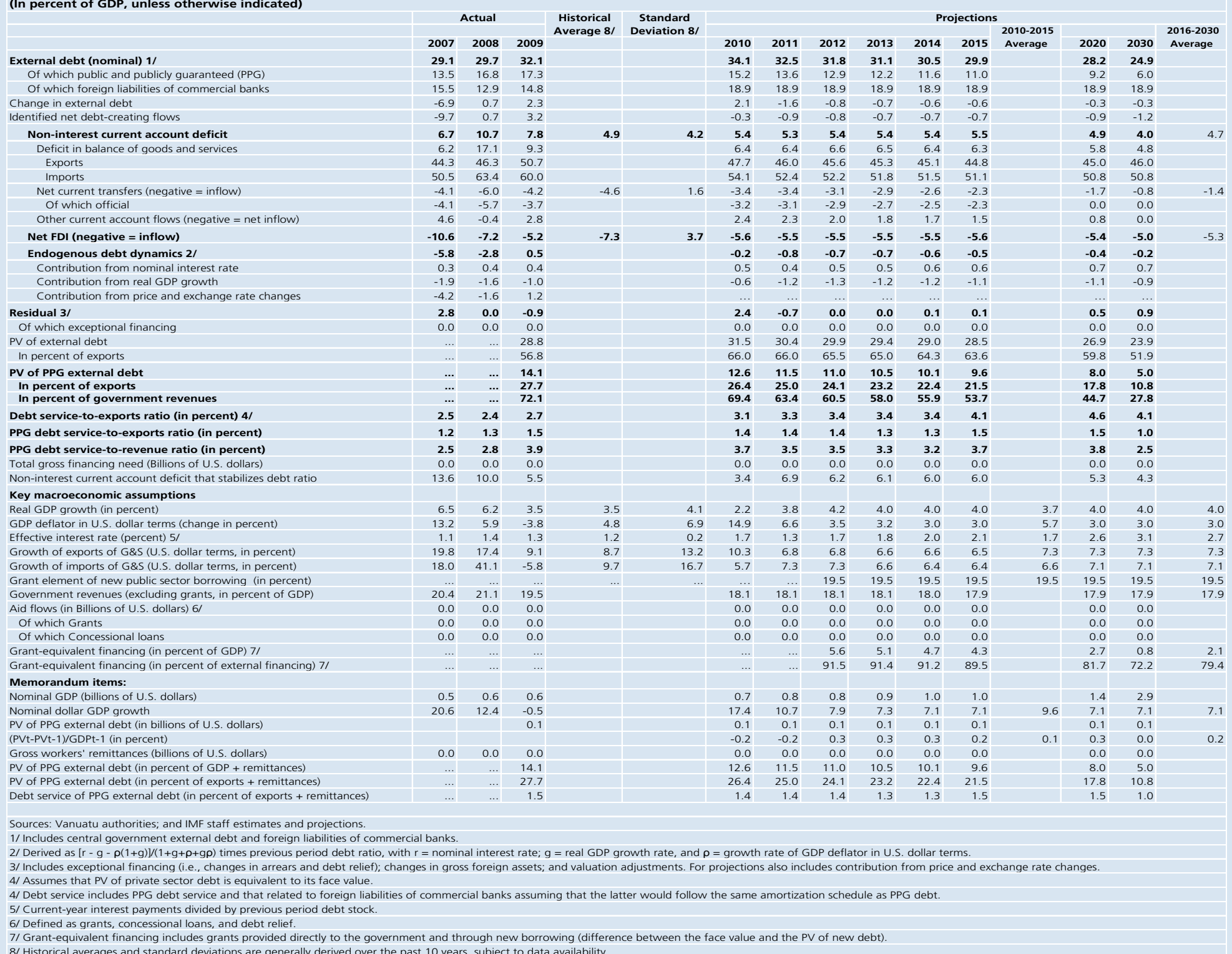




\begin{tabular}{|c|c|c|c|c|c|c|c|c|}
\hline \multicolumn{9}{|l|}{ (In percent) } \\
\hline & & & & Project & & & & \\
\hline & 2010 & 2011 & 2012 & 2013 & 2014 & 2015 & 2020 & 2030 \\
\hline \multicolumn{9}{|c|}{ PV of debt-to GDP ratio } \\
\hline Baseline & 13 & 11 & 11 & 11 & 10 & 10 & 8 & 5 \\
\hline \multicolumn{9}{|l|}{ A. Alternative Scenarios } \\
\hline A1. Key variables at their historical averages in 2010-2030 1/ & 13 & 10 & 7 & 5 & 3 & 1 & $\ldots$ & $\ldots$ \\
\hline A2. New public sector loans on less favorable terms in 2010-2030 2/ & 13 & 11 & 11 & 11 & 10 & 10 & 9 & 7 \\
\hline \multicolumn{9}{|l|}{ B. Bound Tests } \\
\hline B1. Real GDP growth at historical average minus one standard deviation in 2011-2012 & 13 & 12 & 12 & 12 & 11 & 11 & 9 & 5 \\
\hline B2. Export value growth at historical average minus one standard deviation in 2011-2012 3/ & 13 & 15 & 22 & 21 & 21 & 20 & 15 & 7 \\
\hline B3. U.S. dollar GDP deflator at historical average minus one standard deviation in 2011-2012 & 13 & 13 & 13 & 12 & 12 & 11 & 9 & 6 \\
\hline B4. Net non-debt creating flows at historical average minus one standard deviation in 2011-2012 4/ & 13 & 13 & 14 & 14 & 13 & 13 & 10 & 5 \\
\hline B5. Combination of B1-B4 using one-half standard deviation shocks & 13 & 14 & 18 & 18 & 17 & 16 & 13 & 6 \\
\hline B6. One-time 30 percent nominal depreciation relative to the baseline in 2011 5/ & 13 & 16 & 15 & 15 & 14 & 13 & 11 & 7 \\
\hline \multicolumn{9}{|c|}{ PV of debt-to-exports ratio } \\
\hline Baseline & 26 & 25 & 24 & 23 & 22 & 21 & 18 & 11 \\
\hline \multicolumn{9}{|l|}{ A. Alternative Scenarios } \\
\hline A1. Key variables at their historical averages in 2010-2030 1/ & 26 & 22 & 16 & 12 & 7 & 2 & $\ldots$ & $\ldots$ \\
\hline A2. New public sector loans on less favorable terms in 2010-2030 2/ & 26 & 25 & 24 & 24 & 23 & 23 & 20 & 15 \\
\hline \multicolumn{9}{|l|}{ B. Bound Tests } \\
\hline B1. Real GDP growth at historical average minus one standard deviation in 2011-2012 & 26 & 25 & 24 & 23 & 22 & 21 & 18 & 11 \\
\hline B2. Export value growth at historical average minus one standard deviation in 2011-2012 3/ & 26 & 38 & 61 & 59 & 57 & 55 & 42 & 18 \\
\hline B3. U.S. dollar GDP deflator at historical average minus one standard deviation in 2011-2012 & 26 & 25 & 24 & 23 & 22 & 21 & 18 & 11 \\
\hline B4. Net non-debt creating flows at historical average minus one standard deviation in 2011-2012 4/ & 26 & 29 & 31 & 30 & 29 & 28 & 22 & 12 \\
\hline B5. Combination of B1-B4 using one-half standard deviation shocks & 26 & 30 & 39 & 38 & 36 & 35 & 28 & 14 \\
\hline B6. One-time 30 percent nominal depreciation relative to the baseline in 2011 5/ & 26 & 25 & 24 & 23 & 22 & 21 & 18 & 11 \\
\hline \multicolumn{9}{|c|}{ PV of debt-to-revenue ratio } \\
\hline Baseline & 69 & 63 & 61 & 58 & 56 & 54 & 45 & 28 \\
\hline \multicolumn{9}{|l|}{ A. Alternative Scenarios } \\
\hline A1. Key variables at their historical averages in 2010-2030 1/ & 69 & 55 & 41 & 29 & 17 & 6 & $\ldots$ & $\ldots$ \\
\hline A2. New public sector loans on less favorable terms in 2010-2030 2/ & 69 & 63 & 61 & 59 & 58 & 56 & 51 & 38 \\
\hline \multicolumn{9}{|l|}{ B. Bound Tests } \\
\hline B1. Real GDP growth at historical average minus one standard deviation in 2011-2012 & 69 & 66 & 66 & 64 & 61 & 59 & 49 & 30 \\
\hline B2. Export value growth at historical average minus one standard deviation in 2011-2012 3/ & 69 & 85 & 122 & 118 & 114 & 110 & 85 & 37 \\
\hline B3. U.S. dollar GDP deflator at historical average minus one standard deviation in 2011-2012 & 69 & 69 & 70 & 67 & 64 & 62 & 51 & 32 \\
\hline B4. Net non-debt creating flows at historical average minus one standard deviation in 2011-2012 4/ & 69 & 73 & 78 & 75 & 73 & 70 & 56 & 30 \\
\hline B5. Combination of B1-B4 using one-half standard deviation shocks & 69 & 79 & 101 & 97 & 94 & 90 & 72 & 36 \\
\hline B6. One-time 30 percent nominal depreciation relative to the baseline in $20115 /$ & 69 & 88 & 84 & 81 & 78 & 75 & 62 & 39 \\
\hline
\end{tabular}




\section{Debt service-to-exports ratio}

\section{Baseline}

A. Alternative Scenarios

A1. Key variables at their historical averages in 2010-2030 1/

A2. New public sector loans on less favorable terms in 2010-2030 2/

\section{B. Bound Tests}

B1. Real GDP growth at historical average minus one standard deviation in 2011-2012

B2. Export value growth at historical average minus one standard deviation in 2011-2012 3/

B3. U.S. dollar GDP deflator at historical average minus one standard deviation in 2011-2012

B4. Net non-debt creating flows at historical average minus one standard deviation in 2011-2012 4

B5. Combination of B1-B4 using one-half standard deviation shocks

B6. One-time 30 percent nominal depreciation relative to the baseline in 2011 5/

\section{Debt service-to-revenue ratio}

\section{Baseline}

\section{A. Alternative Scenarios}

A1. Key variables at their historical averages in 2010-2030 1/

A2. New public sector loans on less favorable terms in 2010-2030 2/

B. Bound Tests

B1. Real GDP growth at historical average minus one standard deviation in 2011-2012

B2. Export value growth at historical average minus one standard deviation in 2011-2012 3/

B3. U.S. dollar GDP deflator at historical average minus one standard deviation in 2011-2012

B4. Net non-debt creating flows at historical average minus one standard deviation in 2011-2012 4/

B5. Combination of B1-B4 using one-half standard deviation shocks

B6. One-time 30 percent nominal depreciation relative to the baseline in 2011 /

\section{Memorandum item:}

Grant element assumed on residual financing (i.e., financing required above baseline) 6

Sources: Vanuatu authorities; and IMF staff estimates and projections.

1/ Variables include real GDP growth, growth of GDP deflator (in U.S. dollar terms), non-interest current account in percent of GDP, and non-debt creating flows.

2/ Assumes that the interest rate on new borrowing is by 2 percentage points higher than in the baseline, while grace and maturity periods are the same as in the baseline.

3/ Exports values are assumed to remain permanently at the lower level, but the current account as a share of GDP is assumed to return to its baseline level after the shock (implicitly assuming

an offsetting adjustment in import levels).

4/ Includes official and private transfers and FDI.

5/ Depreciation is defined as percentage decline in dollar/local currency rate, such that it never exceeds 100 percent.

6/ Applies to all stress scenarios except for A2 (less favorable financing) in which the terms on all new financing are as specified in footnote 2. 
Table 3 Vanuatu: Public Sector Debt Sustainability Framework, Baseline Scenario, 2007-30

\begin{tabular}{|c|c|c|c|c|c|c|c|c|c|c|c|c|c|c|c|}
\hline \multicolumn{16}{|l|}{ (In percent of GDP, unless otherwise indicated) } \\
\hline & \multicolumn{3}{|c|}{ Actual } & \multicolumn{3}{|c|}{\begin{tabular}{l|l|l} 
& Estimate \\
\end{tabular}} & \multicolumn{9}{|c|}{ Projections } \\
\hline & 2007 & 2008 & 2009 & Average $5 /$ & $\begin{array}{l}\text { Standard } \\
\text { Deviation 5/ }\end{array}$ & 2010 & 2011 & 2012 & 2013 & 2014 & 2015 & $\begin{array}{l}2010-15 \\
\text { Average }\end{array}$ & 2020 & 2030 & $\begin{array}{l}\text { 2016-30 } \\
\text { Average }\end{array}$ \\
\hline Public sector debt $1 /$ & 19.1 & 21.1 & 21.2 & & & 20.2 & 19.7 & 18.7 & 17.8 & 17.2 & 16.6 & & 14.5 & 12.0 & \\
\hline Of which foreign-currency denominated & 13.5 & 16.8 & 17.3 & & & 15.2 & 13.6 & 12.9 & 12.2 & 11.6 & 11.0 & & 9.2 & 6.0 & \\
\hline Change in public sector debt & -3.2 & 2.1 & 0.1 & & & -1.1 & -0.5 & -1.0 & -0.8 & -0.7 & -0.5 & & -0.4 & -0.2 & \\
\hline Identified debt-creating flows & -3.5 & -0.1 & -2.3 & & & 0.9 & -0.5 & -1.0 & -0.8 & -0.7 & -0.5 & & -0.4 & -0.2 & \\
\hline Primary deficit & -0.9 & -0.4 & 0.2 & 0.5 & 2.5 & 2.2 & 0.3 & -0.1 & -0.1 & -0.1 & 0.0 & 0.4 & 0.0 & 0.1 & 0.0 \\
\hline Revenue and grants & 22.3 & 27.7 & 26.8 & & & 25.0 & 24.2 & 23.6 & 23.1 & 22.6 & 22.2 & & 20.5 & 18.7 & \\
\hline Of which: grants & 1.8 & 6.6 & 7.3 & & & 6.8 & 6.0 & 5.5 & 5.0 & 4.6 & 4.2 & & 2.5 & 0.7 & \\
\hline Primary (noninterest) expenditure & 21.4 & 27.3 & 27.1 & & & 27.2 & 24.5 & 23.5 & 23.0 & 22.6 & 22.2 & & 20.5 & 18.8 & \\
\hline Automatic debt dynamics & -2.6 & 0.2 & -2.6 & & & -1.3 & -0.8 & -0.9 & -0.7 & -0.6 & -0.6 & & -0.3 & -0.3 & \\
\hline Contribution from interest rate/growth differential & -1.4 & -1.0 & -0.4 & & & -0.2 & -0.4 & -0.6 & -0.5 & -0.5 & -0.4 & & -0.2 & -0.2 & \\
\hline Of which: contribution from average real interest rate & -0.1 & 0.1 & 0.3 & & & 0.3 & 0.3 & 0.2 & 0.2 & 0.2 & 0.2 & & 0.3 & 0.2 & \\
\hline Of which: contribution from real GDP growth & -1.4 & -1.1 & -0.7 & & & -0.5 & -0.7 & -0.8 & -0.7 & -0.7 & -0.7 & & -0.6 & -0.5 & \\
\hline Contribution from real exchange rate depreciation & -1.2 & 1.3 & -2.2 & & & -1.1 & -0.4 & -0.3 & -0.2 & -0.1 & -0.1 & & $\ldots$ & $\ldots$ & \\
\hline Other identified debt-creating flows & 0.0 & 0.0 & 0.0 & & & 0.0 & 0.0 & 0.0 & 0.0 & 0.0 & 0.0 & & 0.0 & 0.0 & \\
\hline Privatization receipts (negative) & 0.0 & 0.0 & 0.0 & & & 0.0 & 0.0 & 0.0 & 0.0 & 0.0 & 0.0 & & 0.0 & 0.0 & \\
\hline Recognition of implicit or contingent liabilities & 0.0 & 0.0 & 0.0 & & & 0.0 & 0.0 & 0.0 & 0.0 & 0.0 & 0.0 & & 0.0 & 0.0 & \\
\hline Debt relief (HIPC and other) & 0.0 & 0.0 & 0.0 & & & 0.0 & 0.0 & 0.0 & 0.0 & 0.0 & 0.0 & & 0.0 & 0.0 & \\
\hline Other (specify, e.g. bank recapitalization) & 0.0 & 0.0 & 0.0 & & & 0.0 & 0.0 & 0.0 & 0.0 & 0.0 & 0.0 & & 0.0 & 0.0 & \\
\hline Residual, including asset changes & 0.3 & 2.2 & 2.5 & & & -2.0 & 0.0 & 0.0 & 0.0 & 0.0 & 0.0 & & 0.0 & 0.0 & \\
\hline \multicolumn{16}{|l|}{ Other Sustainability Indicators } \\
\hline $\mathrm{PV}$ of public sector debt & $\ldots$ & $\ldots$ & 18.0 & & & 17.5 & 17.5 & 16.8 & 16.1 & 15.7 & 15.3 & & 13.3 & 11.0 & \\
\hline Of which foreign-currency denominated & $\ldots$ & $\ldots$ & 14.1 & & & 12.6 & 11.5 & 11.0 & 10.5 & 10.1 & 9.6 & & 8.0 & 5.0 & \\
\hline Of which external & $\ldots$ & $\ldots$ & 14.1 & & & 12.6 & 11.5 & 11.0 & 10.5 & 10.1 & 9.6 & & 8.0 & 5.0 & \\
\hline PV of contingent liabilities (not included in public sector debt) & $\ldots$ & $\ldots$ & ... & & & 10.0 & 10.0 & 10.0 & 10.0 & 10.0 & 10.0 & & 10.0 & 10.0 & \\
\hline Gross financing need 21 & 0.7 & 2.8 & 2.4 & & & 3.8 & 2.3 & 1.8 & 2.3 & 2.0 & 2.2 & & 1.9 & 1.3 & \\
\hline PV of public sector debt-to-revenue and grants ratio (in percent) & $\ldots$ & $\ldots$ & 67.1 & & & 70.3 & 72.5 & 70.9 & 69.7 & 69.2 & 68.9 & & 64.9 & 58.9 & \\
\hline PV of public sector debt-to-revenue ratio (in percent) & $\ldots$ & $\ldots$ & 92.3 & & & 96.8 & 96.7 & 92.5 & 89.1 & 86.8 & 85.1 & & 74.1 & 61.3 & \\
\hline Of which external $3 /$ & $\ldots$ & $\ldots$ & 72.1 & & & 69.4 & 63.4 & 60.5 & 58.0 & 55.9 & 53.7 & & 44.7 & 27.8 & \\
\hline Debt service-to-revenue and grants ratio (in percent) $4 /$ & 7.0 & 11.3 & 8.0 & & & 6.3 & 8.2 & 8.0 & 10.4 & 8.9 & 9.7 & & 9.5 & 6.5 & \\
\hline Debt service-to-revenue ratio (in percent) $4 /$ & 7.6 & 14.8 & 11.0 & & & 8.6 & 11.0 & 10.4 & 13.3 & 11.2 & 12.0 & & 10.9 & 6.8 & \\
\hline Primary deficit that stabilizes the debt-to-GDP ratio & 2.3 & -2.4 & 0.1 & & & 3.3 & 0.8 & 0.9 & 0.7 & 0.6 & 0.6 & & 0.3 & 0.3 & \\
\hline \multicolumn{16}{|l|}{ Key macroeconomic and fiscal assumptions } \\
\hline Real GDP growth (in percent) & 6.5 & 6.2 & 3.5 & 3.5 & 4.1 & 2.2 & 3.8 & 4.2 & 4.0 & 4.0 & 4.0 & 3.7 & 4.0 & 4.0 & 4.0 \\
\hline Average nominal interest rate on forex debt (in percent) & 1.1 & 1.6 & 1.3 & 1.2 & 0.2 & 1.4 & 1.2 & 1.7 & 1.7 & 1.9 & 2.1 & 1.6 & 2.6 & 2.9 & 2.6 \\
\hline Average real interest rate on domestic debt (in percent) & 2.8 & 2.7 & 5.9 & 3.9 & 1.7 & 4.9 & 6.8 & 2.5 & 3.3 & 3.7 & 3.8 & 4.2 & 5.3 & 3.1 & 4.4 \\
\hline Real exchange rate depreciation (in percent, + indicates depreciation) & -7.9 & 10.0 & -13.4 & -2.6 & 9.7 & -6.6 & $\ldots$ & $\ldots$ & $\ldots$ & $\ldots$ & $\ldots$ & $\ldots$ & $\ldots$ & $\ldots$ & $\ldots$ \\
\hline Inflation rate (GDP deflator, in percent) & 4.8 & 4.8 & 1.3 & 2.7 & 1.7 & 2.8 & 4.0 & 3.5 & 3.2 & 3.0 & 3.0 & 3.2 & 3.0 & 3.0 & 3.0 \\
\hline Growth of real primary spending (deflated by GDP deflator, in percent) & 0.2 & 0.4 & 0.0 & 0.1 & 0.2 & 0.0 & -0.1 & 0.0 & 0.0 & 0.0 & 0.0 & 0.0 & 0.0 & 0.0 & 0.0 \\
\hline Grant element of new external borrowing (in percent) & $\ldots$ & $\ldots$ & $\ldots$ & $\ldots$ & $\ldots$ & $\ldots$ & $\ldots$ & 19.5 & 19.5 & 19.5 & 19.5 & 19.5 & 19.5 & 19.5 & $\ldots$ \\
\hline \multicolumn{16}{|l|}{ Sources: Vanuatu authorities; and IMF staff estimates and projections. } \\
\hline \multicolumn{16}{|l|}{ 1/ Includes central government debt. } \\
\hline \multicolumn{16}{|l|}{$\begin{array}{l}\text { 2/ Gross financing need is defined as the primary deficit plus debt service. } \\
3 / \text { Revenues excluding grants. }\end{array}$} \\
\hline Revenues excluding grants. & & & & & & & & & & & & & & & \\
\hline & & & & & & & & & & & & & & & \\
\hline
\end{tabular}




\begin{tabular}{|c|c|c|c|c|c|c|c|c|}
\hline \multicolumn{9}{|l|}{ ivity Analysis for Key In } \\
\hline \multirow{2}{*}{\multicolumn{9}{|c|}{ (In percent) }} \\
\hline & & & & & & & & \\
\hline & 2010 & 2011 & 2012 & 2013 & 2014 & 2015 & 2020 & 2030 \\
\hline \multicolumn{9}{|l|}{ PV of Debt-to-GDP Ratio } \\
\hline Baseline & 18 & 18 & 17 & 16 & 16 & 15 & 13 & 11 \\
\hline \multicolumn{9}{|l|}{ A. Alternative scenarios } \\
\hline A1. Real GDP growth and primary balance are at historical averages & 18 & 18 & 18 & 17 & 17 & 17 & 17 & 17 \\
\hline A2. Primary balance is unchanged from 2010 & 18 & 19 & 20 & 21 & 22 & 24 & 29 & 36 \\
\hline A3. Permanently lower GDP growth $1 /$ & 18 & 18 & 17 & 17 & 17 & 18 & 21 & 36 \\
\hline \multicolumn{9}{|l|}{ B. Bound tests } \\
\hline B1. Real GDP growth is at historical average minus one standard deviations in 2011-2012 & 18 & 19 & 20 & 21 & 22 & 22 & 26 & 31 \\
\hline B2. Primary balance is at historical average minus one standard deviations in 2011-2012 & 18 & 20 & 21 & 20 & 20 & 19 & 17 & 13 \\
\hline B3. Combination of B1-B2 using one half standard deviation shocks & 18 & 19 & 20 & 20 & 20 & 20 & 21 & 22 \\
\hline B4. One-time 30 percent real depreciation in 2011 & 18 & 23 & 22 & 21 & 20 & 19 & 17 & 13 \\
\hline B5. 10 percent of GDP increase in other debt-creating flows in 2011 & 18 & 25 & 24 & 23 & 23 & 22 & 19 & 14 \\
\hline \multicolumn{9}{|l|}{ PV of Debt-to-Revenue Ratio $2 /$} \\
\hline Baseline & 70 & 73 & 71 & 70 & 69 & 69 & 65 & 59 \\
\hline \multicolumn{9}{|l|}{ A. Alternative scenarios } \\
\hline A1. Real GDP growth and primary balance are at historical averages & 70 & 73 & 74 & 75 & 77 & 78 & 85 & 92 \\
\hline A2. Primary balance is unchanged from 2010 & 70 & 79 & 85 & 92 & 99 & 106 & 140 & 191 \\
\hline A3. Permanently lower GDP growth $1 /$ & 70 & 73 & 73 & 74 & 77 & 80 & 102 & 193 \\
\hline \multicolumn{9}{|l|}{ B. Bound tests } \\
\hline B1. Real GDP growth is at historical average minus one standard deviations in 2011-2012 & 70 & 78 & 84 & 89 & 94 & 100 & 124 & 165 \\
\hline B2. Primary balance is at historical average minus one standard deviations in 2011-2012 & 70 & 81 & 90 & 88 & 88 & 87 & 81 & 70 \\
\hline B3. Combination of B1-B2 using one half standard deviation shocks & 70 & 78 & 85 & 86 & 89 & 92 & 102 & 120 \\
\hline B4. One-time 30 percent real depreciation in 2011 & 70 & 94 & 92 & 90 & 89 & 88 & 81 & 71 \\
\hline B5. 10 percent of GDP increase in other debt-creating flows in 2011 & 70 & 105 & 103 & 102 & 101 & 100 & 92 & 78 \\
\hline \multicolumn{9}{|l|}{ Debt Service-to-Revenue Ratio $2 /$} \\
\hline Baseline & 6 & 8 & 8 & 10 & 9 & 10 & 10 & 7 \\
\hline \multicolumn{9}{|l|}{ A. Alternative scenarios } \\
\hline A1. Real GDP growth and primary balance are at historical averages & 6 & 8 & 8 & 11 & 9 & 10 & 10 & 9 \\
\hline A2. Primary balance is unchanged from 2010 & 6 & 8 & 8 & 11 & 10 & 11 & 12 & 14 \\
\hline A3. Permanently lower GDP growth 1/ & 6 & 8 & 8 & 11 & 9 & 10 & 11 & 13 \\
\hline \multicolumn{9}{|l|}{ B. Bound tests } \\
\hline B1. Real GDP growth is at historical average minus one standard deviations in 2011-2012 & 6 & 9 & 9 & 11 & 10 & 11 & 12 & 13 \\
\hline B2. Primary balance is at historical average minus one standard deviations in 2011-2012 & 6 & 8 & 8 & 11 & 9 & 10 & 11 & 8 \\
\hline B3. Combination of B1-B2 using one half standard deviation shocks & 6 & 8 & 8 & 11 & 10 & 11 & 11 & 10 \\
\hline B4. One-time 30 percent real depreciation in 2011 & 6 & 9 & 9 & 12 & 10 & 11 & 11 & 8 \\
\hline B5. 10 percent of GDP increase in other debt-creating flows in 2011 & 6 & 8 & 9 & 12 & 10 & 11 & 12 & 8 \\
\hline
\end{tabular}




\section{INTERNATIONAL MONETARY FUND}

EXTERNAL

Public Information Notice

RELATIONS

DEPARTMENT

Public Information Notice (PIN) No. 11/59

FOR IMMEDIATE RELEASE

May 23, 2011
International Monetary Fund

$70019^{\text {th }}$ Street, NW

Washington, D. C. 20431 USA

\section{IMF Executive Board Concludes 2011 Article IV Consultation with Vanuatu}

On April 22, 2011, the Executive Board of the International Monetary Fund (IMF) concluded the Article IV consultation with Vanuatu. ${ }^{1}$

\section{Background}

Economic activity is showing signs of a moderate rebound after both external and domestic demand slowed down in 2009-10. Private investment is picking up, tourism is gradually expanding, and agricultural production is increasing partly in response to sharp rises in copra prices. The key downside risks are delays in infrastructure investment and slower tourism growth owing to recent natural disasters in the region. Inflation is ticking up and is expected to reach 4 percent on the back of higher food and oil prices, as well as rising domestic demand.

The balance of payments has been stable. The current account deficit remained high at about 6 percent of GDP in 2010, but was fully financed by FDI inflows and official grants. Official reserves remained around \$160 million (covering six months of imports) in 2010 after rising throughout 2009 (helped by the SDR allocation).

\footnotetext{
${ }^{1}$ Under Article IV of the IMF's Articles of Agreement, the IMF holds bilateral discussions with members, usually every year. A staff team visits the country, collects economic and financial information, and discusses with officials the country's economic developments and policies. On return to headquarters, the staff prepares a report, which forms the basis for discussion by the Executive Board. At the conclusion of the discussion, the Managing Director, as Chairman of the Board, summarizes the views of Executive Directors, and this summary is transmitted to the country's authorities. An explanation of any qualifiers used in summings up can be found here: http://www.imf.org/external/np/sec/misc/qualifiers.htm.
} 
The fiscal deficit deteriorated to 2.7 percent of GDP in 2010 as revenue fell short of budget projections. Total revenue excluding grants shrunk 2.4 percent from 2009, compared with a budgeted increase of 17 percent, reflecting weaknesses in revenue from both external trade and domestic activity. For 2011, the authorities are targeting a substantial reduction in the deficit to 0.7 percent of GDP. They expect to achieve this reduction by maintaining the nominal wage bill broadly at the 2010 level and lowering capital expenditure.

The Reserve Bank of Vanuatu (RBV) maintains an easy monetary stance established at the onset of the global financial crisis. There is ample liquidity in the banking system, and bank lending grew by 12 percent $(\mathrm{y} / \mathrm{y})$ in 2010 , with loans to households and foreign exchange denominated loans increasing significantly. The vatu has changed little in effective terms since 2009.

\section{Executive Board Assessment}

Executive Directors commended the authorities for implementing appropriate policies, leading to a strong rebound in economic activity. The challenge now is to support the recovery while guarding against inflation risks and pushing ahead with fiscal consolidation. Over the medium term, rebuilding fiscal, external, and financial buffers is crucial to enhance Vanuatu's resilience to shocks.

Directors considered this year's budget expenditure target to be appropriate. They stressed the importance of limiting total expenditure to the budgeted level, particularly by containing the wage bill, but encouraged the authorities to allow free play of the automatic stabilizers on the revenue side, if needed. Directors recommended a broadly balanced budget for 2012, which would restore room for policy maneuver against future shocks. Further efforts to mobilize revenue, improve tax administration, and reduce contingent liabilities at public enterprises will also strengthen fiscal buffers.

With rising inflation risks, Directors encouraged early action to unwind the accommodative monetary stance. Rapid growth in credit to households and foreign currency loans calls for continued vigilance and, if necessary, additional prudential measures. Directors saw scope for some exchange rate depreciation as part of a broader macroeconomic response to persistent pressures on Vanuatu's official foreign exchange reserves. More broadly, they underscored the need to safeguard external buffers by maintaining an adequate level of foreign exchange reserves.

Directors welcomed progress in bolstering the soundness of the banking sector, particularly the recent decision to tighten capital and liquidity requirements. They encouraged further efforts to strengthen the regulatory and supervisory framework that covers the whole financial system, including micro lenders and offshore banks.

\footnotetext{
Public Information Notices (PINs) form part of the IMF's efforts to promote transparency of the IMF's views and analysis of economic developments and policies. With the consent of the country (or countries) concerned, PINs are issued after Executive Board discussions of Article IV consultations with member countries, of its surveillance of developments at the regional level, of post-program monitoring, and of ex post assessments of member countries with longer-term program engagements. PINs are also issued after Executive Board discussions of general policy matters, unless otherwise decided by the Executive Board in a particular case.
} 
Vanuatu: Selected Economic and Financial Indicators, 2006-11

\begin{tabular}{|c|c|c|c|c|c|c|}
\hline & & & & Est. & Pro & \\
\hline & 2006 & 2007 & 2008 & 2009 & 2010 & 2011 \\
\hline Output and prices (annual percentage change) & & & & & & \\
\hline Real GDP & 7.4 & 6.5 & 6.2 & 3.5 & 2.2 & 3.8 \\
\hline Nominal GDP & 12.7 & 11.6 & 11.2 & 4.8 & 5.1 & 7.9 \\
\hline Consumer prices (period average) & 2.0 & 3.9 & 4.8 & 4.3 & 2.8 & 4.0 \\
\hline Government finance (in percent of GDP) & & & & & & \\
\hline Total revenue and grants & 20.7 & 22.3 & 27.7 & 26.8 & 25.0 & 24.2 \\
\hline Revenue & 18.9 & 20.4 & 21.1 & 19.5 & 18.1 & 18.1 \\
\hline Tax & 16.8 & 18.2 & 19.1 & 17.2 & 16.5 & 16.5 \\
\hline Non-tax & 2.1 & 2.2 & 2.0 & 2.3 & 1.7 & 1.7 \\
\hline Grants & 1.8 & 1.8 & 6.6 & 7.3 & 6.8 & 6.0 \\
\hline Total expenditure and net lending & 20.2 & 22.0 & 27.9 & 27.6 & 27.7 & 25.1 \\
\hline Current expenditure & 17.4 & 19.4 & 18.6 & 18.6 & 19.8 & 19.0 \\
\hline Capital expenditure & 2.1 & 2.6 & 7.6 & 9.0 & 7.3 & 6.1 \\
\hline Overall balance & 0.5 & 0.3 & -0.2 & -0.7 & -2.7 & -1.0 \\
\hline Money and credit (annual percentage change) & & & & & & \\
\hline Broad money (M2) & 7.0 & 16.1 & 13.2 & 0.5 & -6.0 & ... \\
\hline Net foreign assets & 10.5 & 15.0 & 9.0 & -18.3 & -34.6 & $\ldots$ \\
\hline Domestic credit & 7.2 & 10.6 & 36.7 & 22.1 & 17.4 & $\ldots$ \\
\hline Credit to private sector & 9.7 & 12.3 & 43.3 & 19.9 & 11.6 & $\ldots$ \\
\hline Interest rates (in percent, end of period) & & & & & & \\
\hline Deposit rate (vatu deposits) & 1.9 & 2.0 & 2.7 & 3.2 & 1.8 & $\ldots$ \\
\hline Lending rate (vatu loans) & 11.3 & 10.3 & 10.3 & 10.9 & 10.3 & $\ldots$ \\
\hline Balance of payments & & & & & & \\
\hline Current account (in millions of U.S. dollars) & -28.4 & -36.9 & -65.8 & -48.5 & -41.0 & -43.7 \\
\hline (In percent of GDP) & -6.5 & -7.0 & -11.1 & -8.2 & -5.9 & -5.7 \\
\hline Of which: tourism exports (in millions of U.S. dollars) & 104.2 & 137.0 & 170.6 & 186.9 & 219.6 & 233.9 \\
\hline Merchandise exports, f.o.b. (in millions of U.S. dollars) & 37.7 & 29.7 & 41.7 & 55.2 & 51.4 & 55.0 \\
\hline (Annual percentage change) & -1.3 & -21.2 & 40.7 & 32.1 & -6.8 & 7.0 \\
\hline Merchandise imports, f.o.b. (in millions of U.S. dollars) & 141.2 & 176.0 & 265.2 & 247.0 & 246.3 & 267.2 \\
\hline (Annual percentage change) & 7.6 & 24.6 & 50.6 & -6.8 & -0.3 & 8.5 \\
\hline Gross official reserves (end of period) & & & & & & \\
\hline In millions of U.S. dollars & 105.1 & 119.6 & 115.3 & 148.6 & 161.4 & 157.2 \\
\hline In months of corresponding imports of goods (on c.i.f. basis) & 7.5 & 6.8 & 4.4 & 6.0 & 6.6 & 5.9 \\
\hline In months of prospective imports of goods (on c.i.f. basis) & 6.0 & 4.5 & 4.7 & 6.0 & 6.1 & 5.4 \\
\hline Public debt & & & & & & \\
\hline Total debt (in percent of GDP) & 22.2 & 19.1 & 21.1 & 21.2 & 21.0 & 20.4 \\
\hline External debt (in percent of GDP) $1 /$ & 15.8 & 13.5 & 16.8 & 17.3 & 16.0 & 14.4 \\
\hline External debt service $2 /$ & 1.3 & 1.2 & 1.3 & 1.5 & 1.4 & 1.4 \\
\hline
\end{tabular}

Sources: Vanuatu authorities; and IMF staff estimates and projections.

$1 /$ Medium- and long-term public debt only, denominated in local currency.

$2 /$ In percent of exports of goods and non-factor services. 